تاريخ الإرسال (2020-25)، تاريخ قبول النشر (2020-11-07)

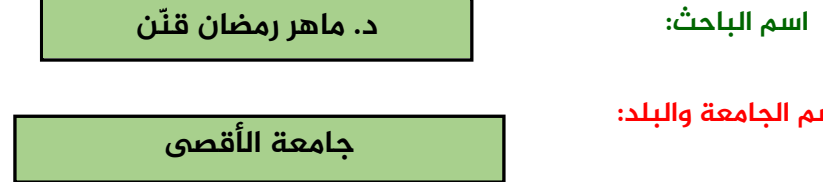

* البريد الالكتروني للباحث المرسل:

\title{
الإيقاع الداخلي في ديوان العودة
}

E-mail address

maherqanan@hotmail.com

تهدف الدراسة إلى الكشف عن الظواهر الإيقاعية الداخلية في ديوان العودة؛ فالموسيقى لها دور مؤثر في متلقي النص الشعري سواء أكان مستمعاً أو قارثًا، والإبداع في النص الشعري يتطلب التوقف عند البنى الصوتية التي تمثل جزءًا لا يمكن إهماله في بنية القصيدة، وذلك من خلال الموسيقى الداخلية المتنوعة التي يزخر بها الديوان، ويتطلب هذا البحث عن الدلالة الوظيفية والنفسية التي أثرت في الشاعر منذ اللحظة الأولى التي كتب فيها القصيدة .

\section{Abstract:}

\section{Internal rhythm in Diwan al-Awda}

Disclose the musical phenomena, internal, in the Court of Return. Music has an influential role for the recipients of the poetic text, whether it is a listener or reader.

Upon creativity in the poetic text requires stopping at the vocal structures that are part of it.

Neglecting the structure of the poem, through the diverse internal music, which is abundant in the Diwan and this, requires research on its functional and psychological significance, which influenced the poet, from the first moment, in which the poem was written.

Keywords: The inner rhythm, Diwan al-Awda, Verbal and moral improvements. 
تعدّ الدراسات الحديثة التي تهتم بالإيقاع الموسيقى للنص الثعري إحدى أهم الدراسات التي تهتمّ بالنص على مستوى الثكل والمضمون، وتعدّ الأسلوبية النص الإبداعي هو البؤرة الأولى التي ينطلق منها الدارس، وعليه يجب أن يكون الباحث مهتمًا بالنص وحده؛ ليستطيع اكتثافه من جديد، وإلا ظلّت معاني الثاعر وأهدافه مقصورة عليه؛ لذا فإنّ الدراسات الحديثة مهتمة بالإيقاع الثعري بما فيه من إيقاع داخلي نابع من صميم النص كضرورة تعبيرية تسهم في تثكيل البنية الهيكلية له، فالإيقاع الداخلي للنص يمكن اعتباره " تشكيلة من التشكيلات والعلاقات التي يتبلور بعضها في بحور متميزة قائمة بذاتها، بينما يشكل

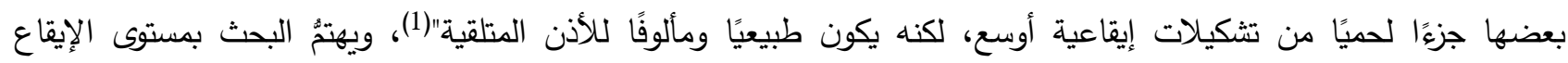
الداخليّ في ديوان العودة، ولعل دراسة الموسيقى الإيقاعية تتثكل من "التكرار المنسق لوضع أو قوة، لمعنى أو حركة، وهو أحد أنواع الوحدة؛ لأثّه تركيز على حركة أو نغم أو لفظ معين ليظهر في تتاوب الحركة والسكون والأنوار والظلام، عودة البداية في النهاية، رجوع القرار في الأغنية، ردّ العجز على الصدر في الثعر، تكرار قافية واحدة، أو قوافٍ متتاوبة، رجوع نوبة واحدة، أو

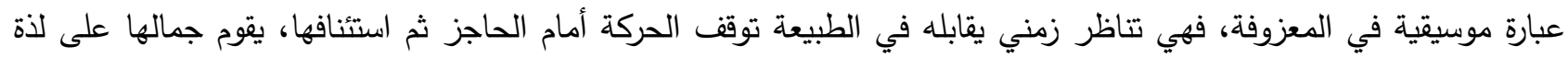

انتظار ما نستبق حدوثه"(2).

لم يعتمد الثاعر العربي قديمًا وحديثًا في شعره الغنائي على الموسيقى الموجودة في الوزن والقافية فقط، بل كان يتطلع

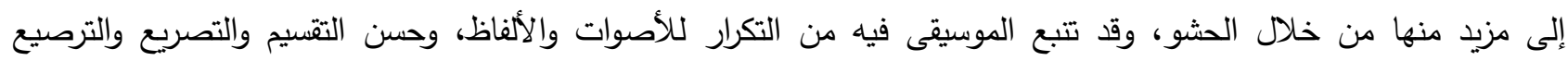
والجناس وغير ذلك، ويراها شوقي ضيف أنّها "تتبع من اختيار الثاعر لكلماته، وما بينها من تلائم في الحروف والحركات، وكأنّ وندئ

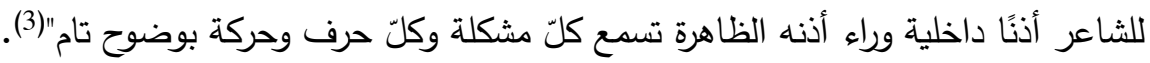

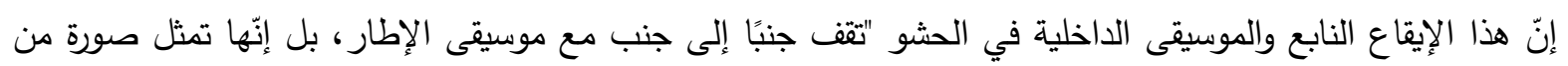

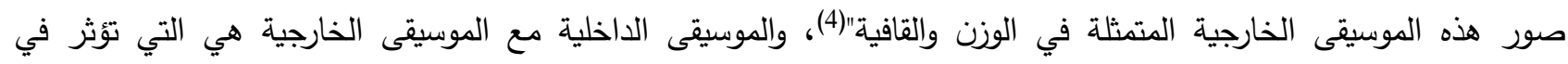
المتلقي، فتأسر لبّه وفكره، فيميل بها طربًا، وكلّما كانت موسيقى الثعر وإيقاعاته جذابة أثرت في المتلقي تأثيرًا واضحًا.

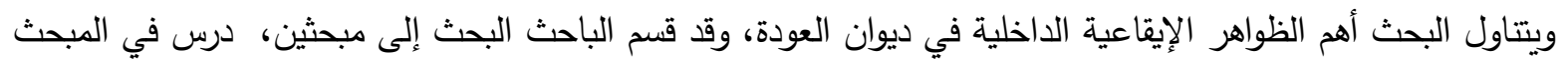
الأول(الإيقاع في المحسنات البديعية المعنوية) ومنها: الطباق، والتقسيم، واللفت والنشر، والإيغال، ودئه ودرس في في المبحث الثاني

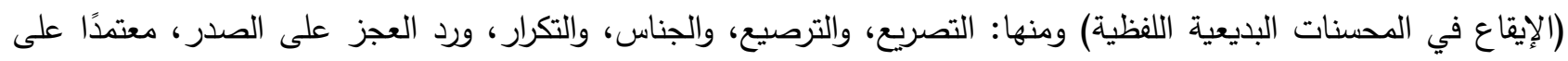

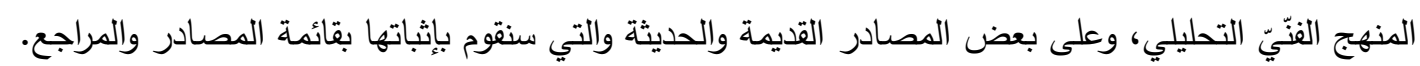

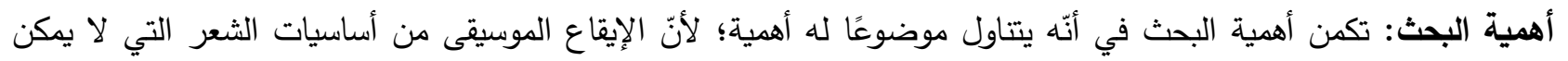

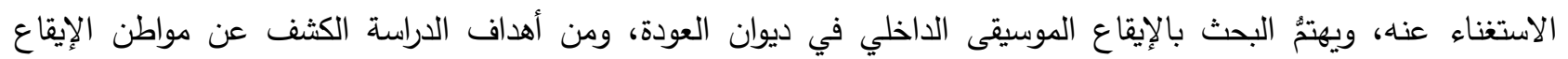

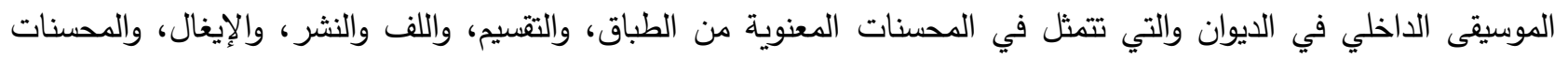

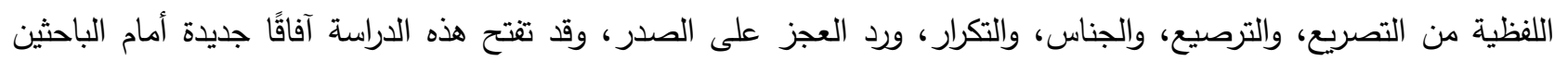
للكثف عن مكامن الإبداع عند العديد من الثعراء، وديوان العودة من الطبعات الحديثة الصادرة عن رابطة الكتاب والأدباء الفلسطينيين في مدينة غزّة، ويضم بين صفحاته مائة وثلانًا وستين قصيدة لشعراء وشاعرات من قطاع غزة، والديوان كما يتضح من اسمه يتحدث عن فعاليات حقّ العودة التي قام بها الفلسطينيون في قطاع غزة.

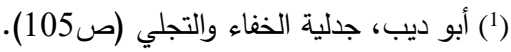

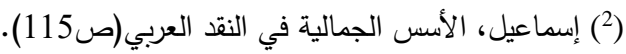

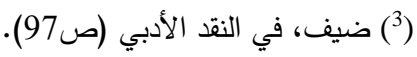




\section{المبحث الأول \\ الإيقاع في المحسنات البليعية المعنوية}

يعتقد الكثيرون أنّ الإيقاع موجود في الوزن فقط، وهو اعتقاد لا يمكن اعتماده في الحديث عن موسيقى الثعر ؛ لأنّ الإيقاع أشمل من الوزن، فالوزن عبارة عن ظاهرة صوتية تظهر للمتلقي من تساوي أجزاء البيت الثعري وترددها على مسافات أو مقادير

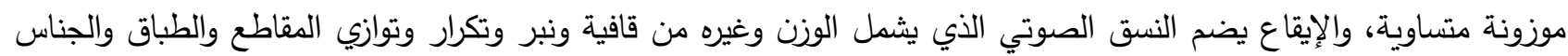

\section{وغير ذلك من المحسنات البديعية.}

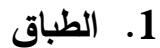

من المحسنات البديعية المعنوية التي استخدمها الثعراء في ديوان العودة، وكان له الأثر الواضح على الموسيقى الداخلية في

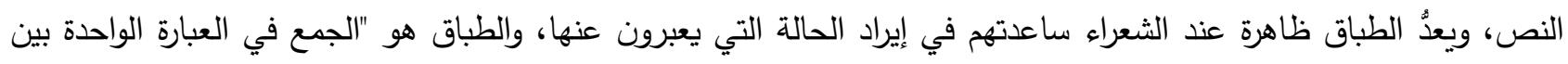
معنيين متقابلين على سبيل الحقيقة أو على سبيل المجاز ولو إيهاماً..."(1).

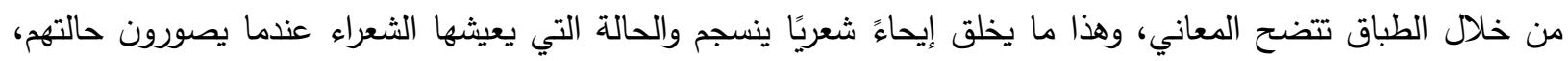
فحين يتحدث الثاعر عن الوطن وهموم الثعب الفلسطيني وحقوقه المسلوبة...، يكثر من ذكر الثنائيات الضدية، لإظهار الحياة بكل ألوانها، وبما فيها من تتاقض أثرّت في الثعب منذ نكبته مرورًا بكلِّ ألوانها وأشكالها، حتى غدت أئى أيام الفلسطيني بين يوم وليلة

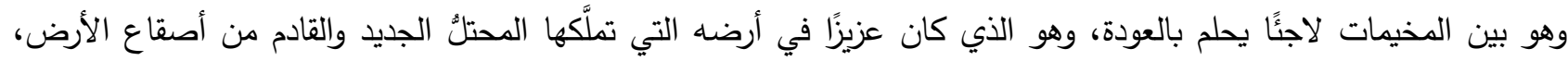

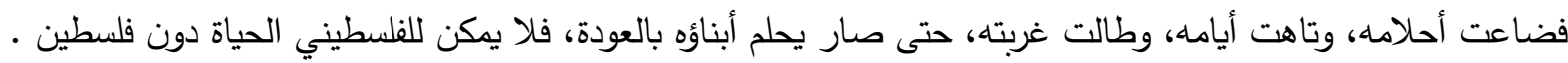
ومن أمثلة الطباق قول محمد رباح مصورًا حال الثباب وهم على حدود غزة (2) :

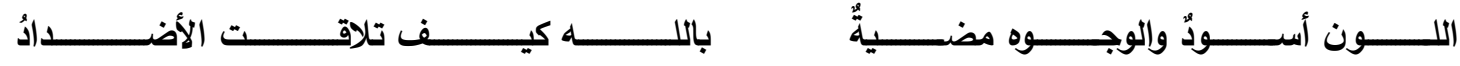

يصف الثاعر حال الشباب وهم يشعلون الإطارات حول السياج الفاصل بين غزة وفلسطين حيث الوطن والأرض والعزة،

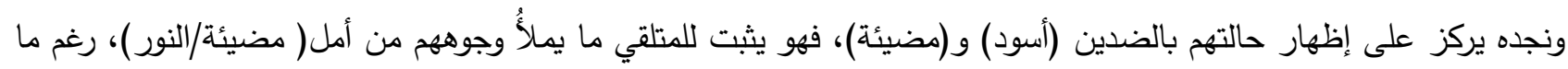

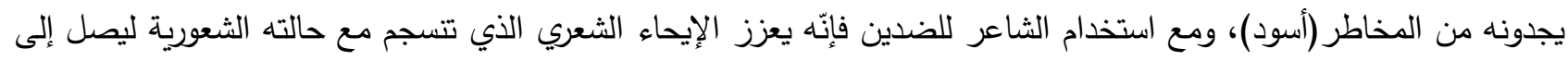
الاستفهام في الثطر الثاني مصحوبًا بالتعجب عن كيفية اجتماع الأضداد التهاد. وحين تصف أفنان أبو موسى الثباب تقول(3):

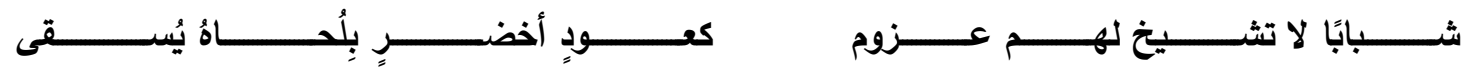

فقد جاء الطباق في قولها(شباب) و(تثيخ)، ورغم أن المعنى واضح من خلال الطباق، فإنّ الثاعر يؤكد في الثطر

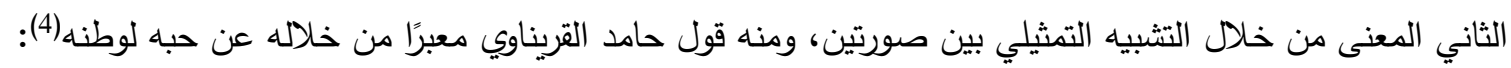

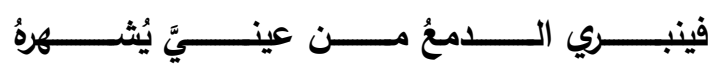

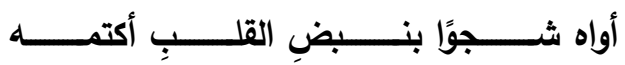


فقد أظهر الثاعر صورة حبه للوطن عن طريق الضدين (أكتمه) و(يشهره)، وبهذا يوحي بمدى حبه ، فهو يحاول إخفاء الحزن الذي يكتمه في قلبه لما أصاب وطنه، لكن هيهات أن يستمر هذا الإخفاء؛ لأنّ الدمع سرعان ما يكثفه هذا الثجو، وهن وهو بذلك يلفت انتباه المتلقي عن طريق الطباق وخاصة أنه جاء في آخر تفعيلتين من الثطر الأول والثاني أي في العروض مأه والضرب.

ومنه قول أفنان أبو موسى (1):

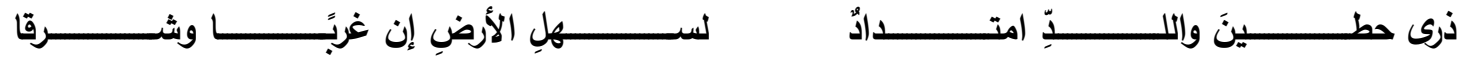

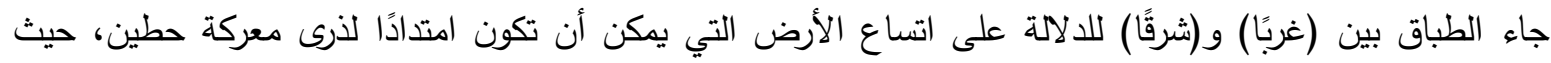

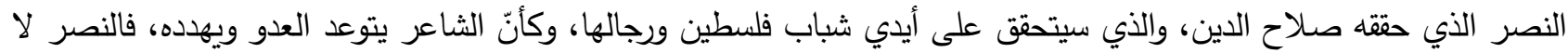
يكون إلا على ما كان عليه صلاح الدين من صلاح، ومنه قول مصطفى منصور (2):

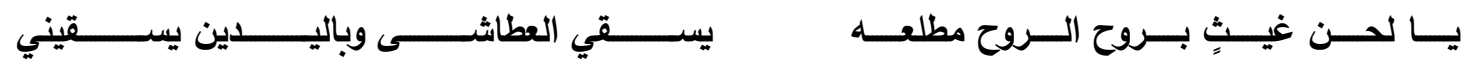

جاء الطباق في الجمع بين الفعل (يسقي) والاسم (العطاشى)، ويريد الثاعر أن حب للوطن جعله يشعر بالعطش، لكن الوطن يسقي العطاشى من يديه، لتكتمل صورة الطباق مع الاستعارة المكنية، وبذلك يضمن الطباق بالاستعارة لتكتمل الصورة.

$$
\text { ومن الطباق قوله(3): }
$$

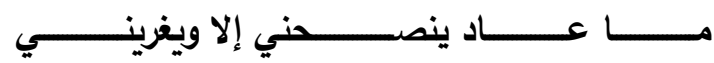

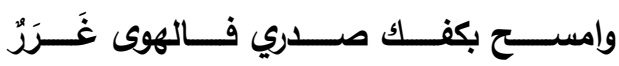

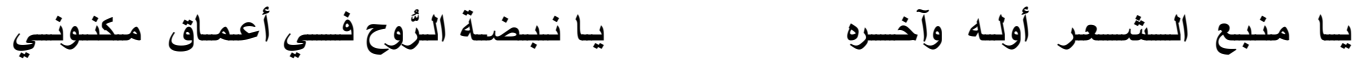

$$
\begin{aligned}
& \text { الطباق بين الفعلين (ينصحني) و(يغريني) في البيت الأول، وفي البيت الثاني بين اسمين (أوله) و (آخره). } \\
& \text { وقد يأتي الطباق بالسلب بين لفظتين إحداهما موجبة، والثانية سالبة. }
\end{aligned}
$$

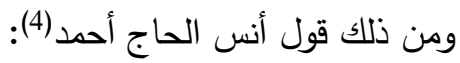

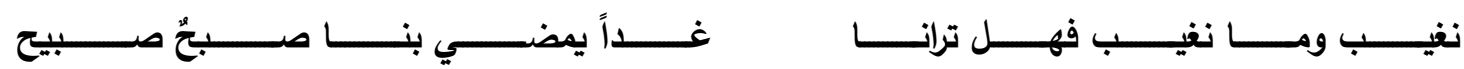

فالطباق السلب واقع بين (نغيب) و(ما نغيب)، وقد تبدو موسيقى البيت الداخلية من خلال الطباق ومن خلال تكرار الحروف في البيت الواحد، مما يساعد في إظهار موسيقى النص الثعري بأكمله. ومنه قول محمد سعيد رباح(5):

والأولادُ الأحسَ

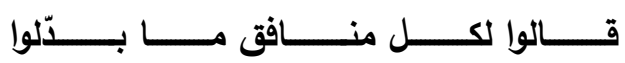

ومنه قول محمد رامي السطري(6):

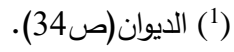

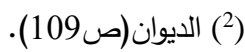

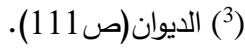

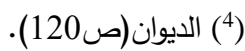

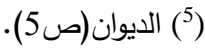

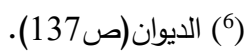




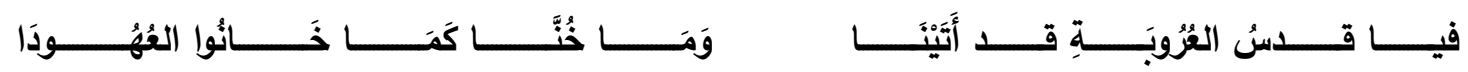

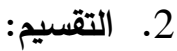

وهو عند أبي هلال العسكري " أن تقسّم الكلام قسمة مستوية تحتوى على جميع أنواعه، ولا يخرج منها جنس من أجناسه"(1)،

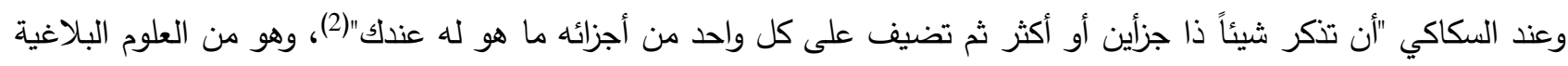

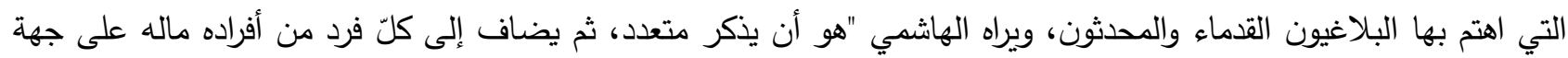
التعيين"(3)، كما جعل بعض النقاد صحة التقيه سبياً من أسباب جمال الثعر (4). يعطي التقسيم جمالاً شكلياً وإيقاعيًا، وله أشكال مختلفة، منها: الثنائي والثلاثي والرباعي، ويظهر التقسيم الرباعي الجميل في ني قول الحسن أبو قادوس(5):

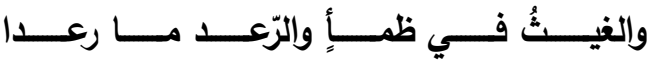

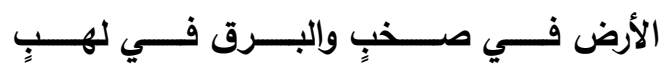

ونجد الإيقاع الموسيقى في البيت السابق من التقسيم الرباعي الجميل الذي ينتهي بتكرار الباء المنون بالكسر في الثطر

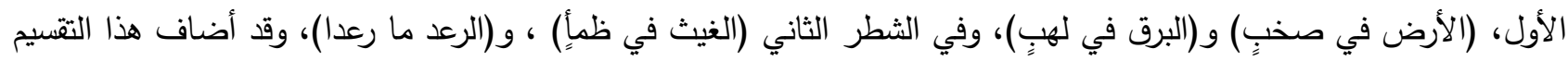
بجانب الوزن والقافية نغدة موسيقية واضحة من خلال تقسيم البيت إلى أقسام متساوية أو شبه متساوية، مما يسهم في إظهار الموسيقى في البيت. ومن التقسيم الرباعي الجميل الوارد في الديوان قول سمية وادي(6):

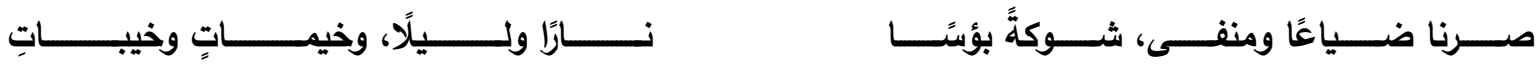

قسمت الثاعرة حال الشعب الفلسطيني بعد نكبته إلى أقسام أربعة هي: الضياع في المنفى، شوكة بؤسًا، نارًا وليلًا، وخيماتٍ وخيبات، وهذا التقسيم شبه المتساوي في الحركات والسكنات أدى إلى إظهار موسيقى البيت بشكل واضح. ومنه قولها(7):

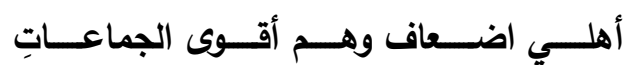

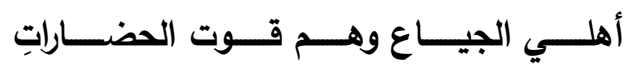

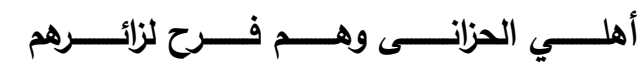

أهلــي الضــياع وهــم وطـن لمـن نصــروا

إنّ الإيقاع ونغمته الموسيقية الجميلة واضحة، من خلال التقسيم الذي جعلته الثاعرة في الأبيات التي أصبحت شبه متساوية، حتى في الايقاع وما ينتج عنه من موسيقى داخلية تلعب دورها في غنائية القصيدة مع الوزن والقافية وغيرهما.

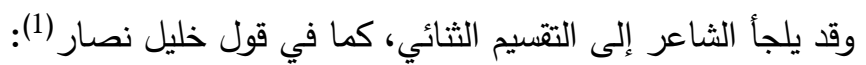

$$
\begin{aligned}
& \text { (1) (1) العسكري، الصناعتين(ص341). }
\end{aligned}
$$

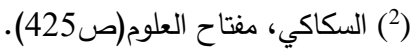

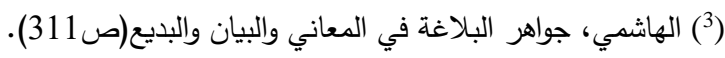

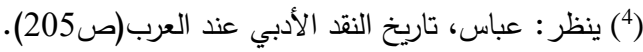

$$
\begin{aligned}
& \text { (5) (5) الديوان(ص) (12). }
\end{aligned}
$$

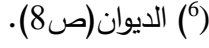

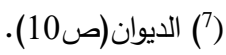




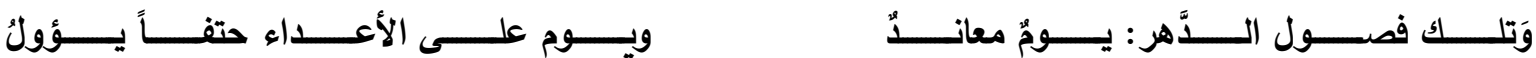

فقد قسم الثاعر الأيام من منظوره الخاص إلى قسمين: (يوم معاند)، بحيث يكون هذا اليوم على الثاعر وقومه فلا يعرفون للنصر طريقًا، و(يوم على الأعداء حتفًا)، بحيث يكون الموت في هذا اليوم على الأعداء، وهذا التقسيم الثنائي أضاف مع التكرار لكلمة (يوم) ورد العجز على الصدر نغمة موسيقية واضحة.

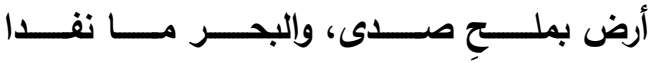

$$
\text { ومنه قول حسن أبو قادوس (2): }
$$

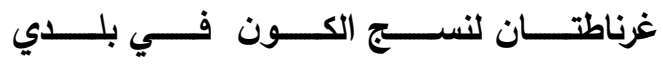

يتضح من التقسيم السابق النغمة الموسيقية التي تتساب كلحن جميل من حسن التقسيم الذي يكاد يكون متساويًا في كل

وهكذا يمكن أن يضيف حسن التقسيم الذي استخدمه الثعراء في ديوان العودة نغمة موسيقية، فيكوّن بذلك نغمة داخلية للنص

هو فنٌّ عرفه النقاد العرب والبلاغيون منذ القدم، وهو "أن تلف بين شيئين في الذكر ثم تتبعهما كلامًا مشتملًا على متعلق

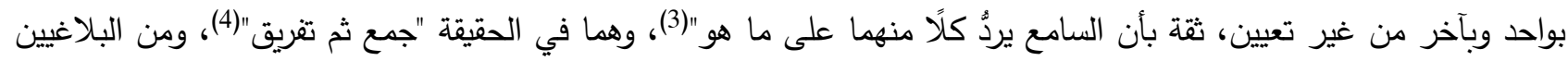

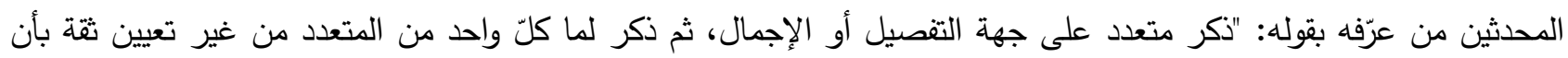

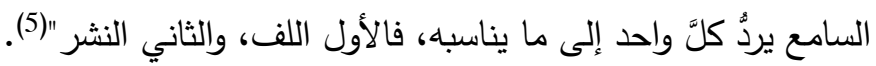
وهو لون من ألوان البلاغة وخاصة من علوم البديع الذي يزين الثاعر بها نظمهاه، ليكمل اللفت والنشر على التقسيم والترصيع والتصريع... والمحسنات الأخرى الموسيقى الداخلية للنص، وقد أجاد الثعراء في استخدام هذه المحسنات البندئ لبديعية. ومنه قول محمد رباح(6):

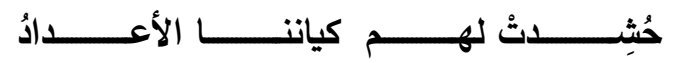

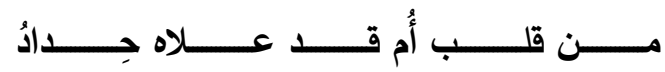

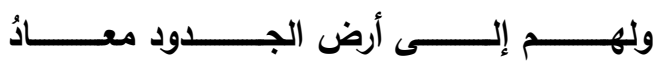

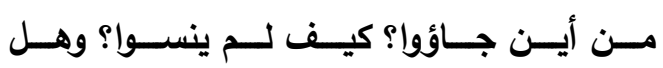

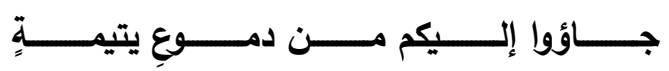

يجعل الثاعر من الاستفهام في البيت الأول مثاراً للدهثة عند المتلقي، وهو ما يمكن اعتباره اللف، فالثعر يسأل(من أين

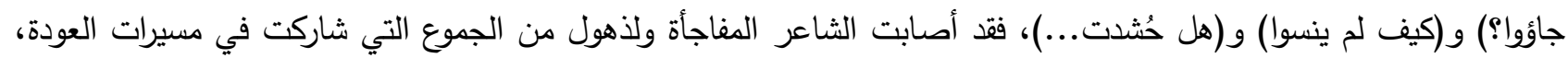


لكن الإجابة لم تتأخر عن المتلقي، ليأتي بها الثاعر في البيتين الثاني والثالث بالنشر عن طريق التوضيح وبيان ما هو خفي عن

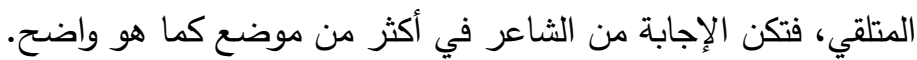
ومنه قول حامد القريناوي(1):

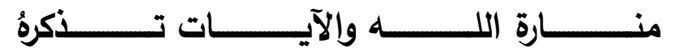
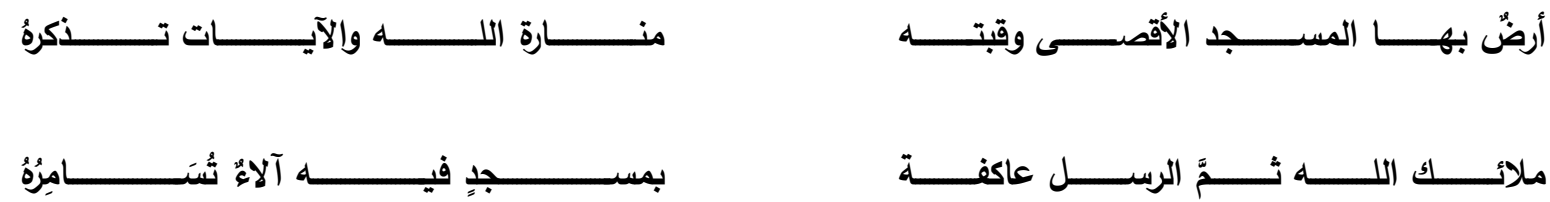

ملائـــــك اللـــــهـه ثــــمَّ الرســـــل عاكفـــــة

وهذا النوع من اللف والنشر المجمل الذي يكون فيه اللف مجملاً يشتمل على عدد، (أرض بها المسد الأقصى وقبته)

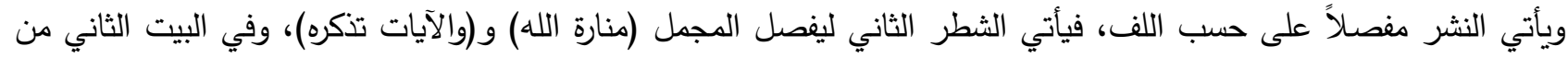

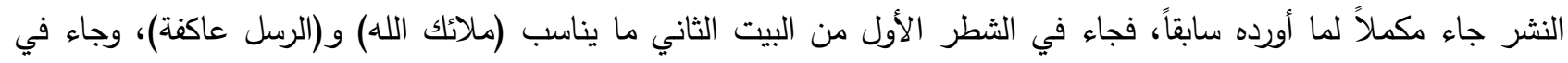

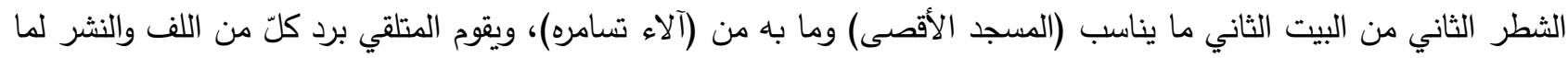
يتناسب، وبذلك يخلق الثاعر الموسيقى الداخلية في النص، لتكتمل مع موسيقى الوزن والقافية. ومنه قول محمود الحديدي)(2):
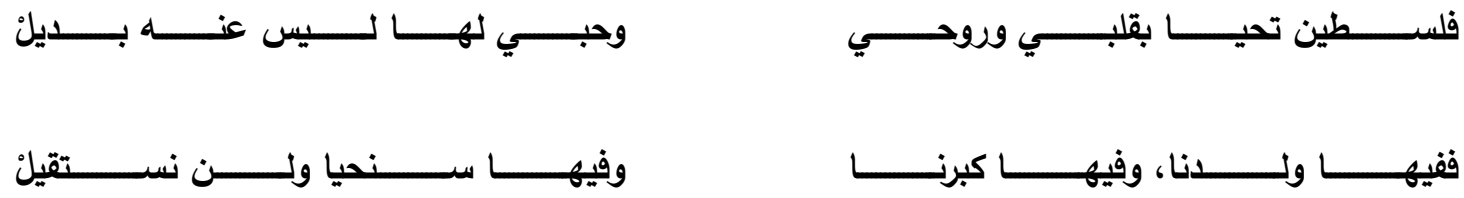

ففي البيت الأول لف، وفي البيت الثاني نشر، وكأنّ الثاعر يوضح لنا سر تمسكه بفلسطين التي تحيا بقلبه وروحه، عن

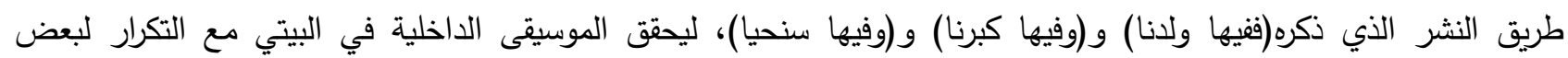

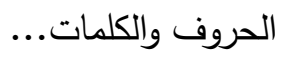

إن سرّ الجمال في هذا المحسن البديعي يكمن في " بيت واحد خالياً من الحشو والتعقيد، جامعاً بين سهولة اللفظ

والمعاني المخترعة"(3).

وهكذا يوظف بعض الشعراء اللف والنشر في الديوان، وهم يؤكدون بذلك أهميته من خلال ما يمكن أن يحققه من موسيقى

$$
\text { 4اخلية في النص الثعر • الإيغال }
$$

وهو "أن يستوفى معنى الكلام قبل البلوغ إلى مقطعه؛ ثم يأتي بالمقطع فيزيد معنى آخر يزيد به وضوحاً وشرحاً وتوكيداً

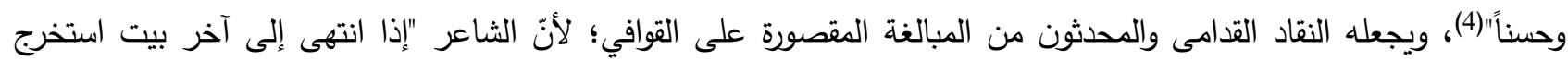

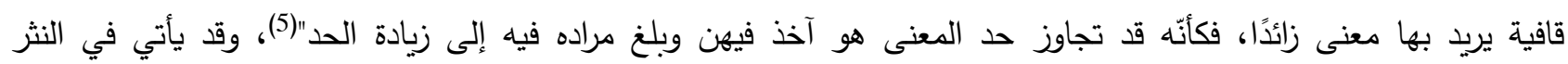

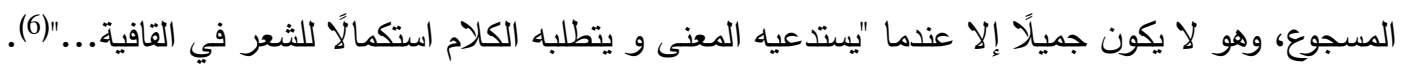

$$
\begin{aligned}
& \text { (1) الديوان(ص25). } \\
& \text { (2) (ل) الديوان(ص99). } \\
& \text { (3) عتيق، علم البديع(ص177). } \\
& \text { (4) العسكري، الصناعتين(ص380). } \\
& \text { (5) عتيق، علم البديع(ص113). }
\end{aligned}
$$

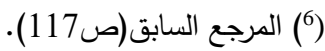


يحتوي ديوان العودة على شواهد كثيرة من الإيغال الجميل الذي استطاعت قريحة الثعراء البناء عليه، وقد أفادت هذه الثواهد المعنى وضوحًا، تطلبه الثعر فكانت القافية التي تلعب دورًا مهمًا في البناء الموسيقي، وخاصة في الثعر الذي يحتاج إلى لـى وزن وقافية واحدة، ومن الشواهد الثعرية على ذلك قول منى حمادة (1) :

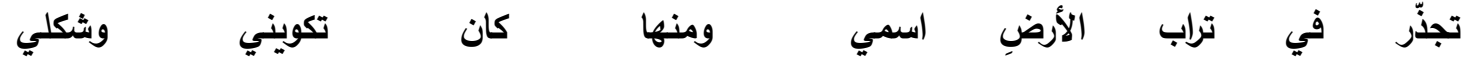

تحاول الثاعرة وصف العلاقة التي تربطها بأرضها (فلسطين)، وتبين أن اسمها متجذر بها منذ التكوين الأول، وهي بذلك استوفت المعنى الذي تريده عند قولها (تكويني)؛ ولكنها احتاجت إلى قافية تتسجم مع قافية القصيدة، ولتنسجم موسيقى البيت من ناحية الوزن ومن ناحية القافية، لذا لجأت إلى إضافة (وشكلي)، رغم أن الثكل يمكن فهمه من خلال كلمة (تكويني)، فهي تشمل الثكل وغيره، وبذلك زاد على المعنى عندما خصصت الثاعرة الثكل دون غيره من الصفات الأخرى.

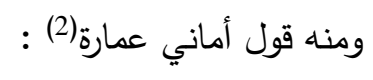

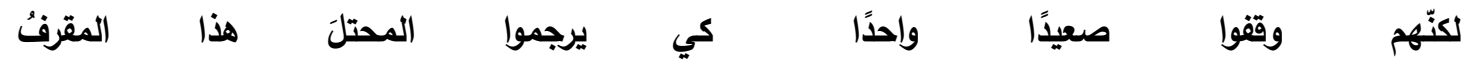

تصف الشاعرة المتظاهرين على الحدود الشرقية لمدينة غزة، وكيف اصطفوا متحدين، بهدف رجم المحتل كما يصطف الحجيج لرجم الثيطان على صعيد عرفات، والصورة بذلك اكتمل معناها، لكن الثاعرة احتاجت القافية في البيت، فلجأت إلى لى الإيغال لإكمال صورة المحتل، فزادت بذلك المعنى عندما وضحت صورته ووصفته بالمقرف، كما حققت الموسيقى البيت من خلال

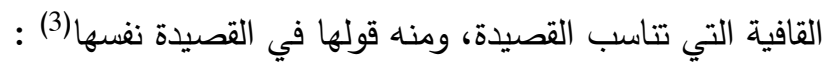

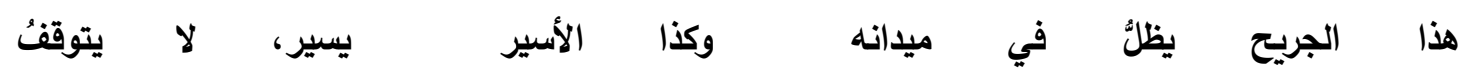
الثاعرة هنا تبين ثبات الفلسطيني في مواجهة الاحتلال، فهو لا يتراجع، فالجميع يشارك في مسيرات العودة ولا يتأخر أحد، حتى المُصاب الذي أُصيب قبل ذلك يبقى ثابتًا ولا يتأخر عن واجبه، وكذلك الأسير يبقى سائرًا في ميدانه، وقد اكتمل للثاعرة المعنى عند قولها (يسير)؛ ولكنها أضافت وبيّنت موقف الأسير الذي يسير دون توقف بقولها (لا يتوقف)، بذلك يكون الإيغال قد زوّد المعنى وأفاد موسيقى القافية في القصيدة.

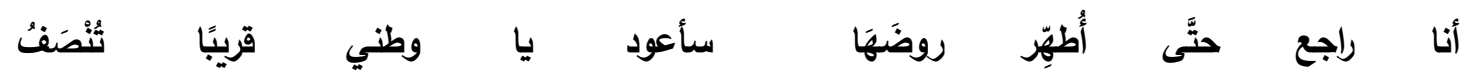
فقد وقع الإيغال في قولها(تتصف)، حيث اكتمل معنى البيت عند قولها (قريبًا)؛ ولكنها احتاجت إلى القافية، وقد أفادت من خلاله زيادة المعنى وزيادة في موسيقى البيت. ومنه قول مصطفى منصور (5):

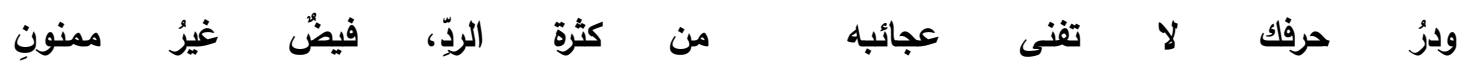

\begin{tabular}{|c|}
\hline (1') الديوان(ص181). \\
\hline (2) الديوان(ص105). \\
\hline (3) الديوان(ص106). \\
\hline (4) الديوان(ص107). \\
\hline (5) الديوان(ص110). \\
\hline
\end{tabular}


يوضح الثاعر مكانة وطنه بين الأمم، فهي التي لا تتنهي عجائب درِ حروفها من كثرة الردود، وقد اكتمل المعنى عند قوله (من كثرة الردّ)؛ ولكن الثاعر أراد أن يزيد المعنى فقال(فيضٌ غيرُ مدنون)، كما أفاد انسجام قافية البيت مع قافية القصيدة، وبذلك يحقق الشاعر موسيقى البيت والنص. لقد ظهر الإيغال كمحن بديعي في العديد من قصائد ديوان العودة، وقد أفاد زيادة في المعنى الذي أراده الثعراء، وجاء ليحقق قافية البيت لإظهار موسيقى النص من خلال وزنه وقافيته، وكلما كان الإيغال غير متكلف فإنَّه يحقق هدفه، فلا جمال في كلِّ إيغال متكلف يتعده الثاعر لإظهار قدراته.

\section{المبحث الثاني}

\section{الإيقاع في المحسنات البليعية اللفظيَّة}

1.

يتميَّز الثعر ذو الثطرين عن غيره بمميزات تؤكد أصالته التراثية، وقد أثثتت الدراسات الأدبية قديمًا وحديثًا أهمية الموسيقى بالنسبة للشعر ، فقد تكون من علامات التغريق بينه وبين غيره، ومن مصادر الموسيقى الداخلية للنص الثعري التصريع،

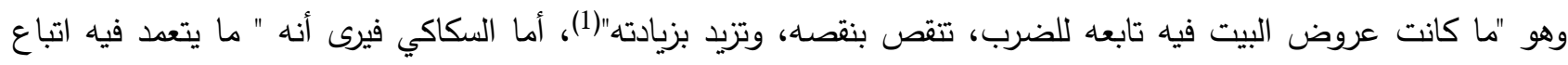
العروض الضرب في وزنه ورويه..."(2). اعتمد الثعراء قديمًا على التصريع اعتمادًا كبيرًا خاصة في مطلع القصائد؛ لأنه يجذب انتباه التباه المتلقي خاصة إذا أُلقيت

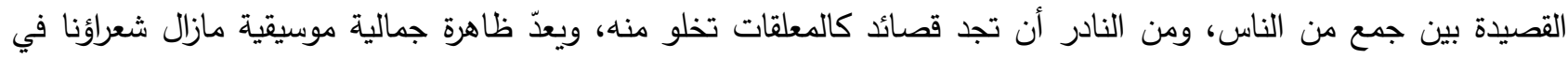

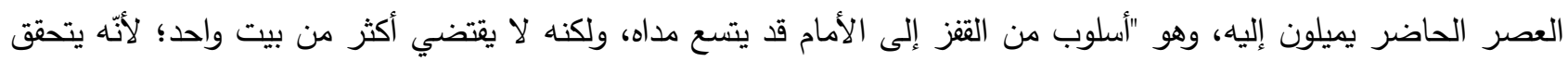

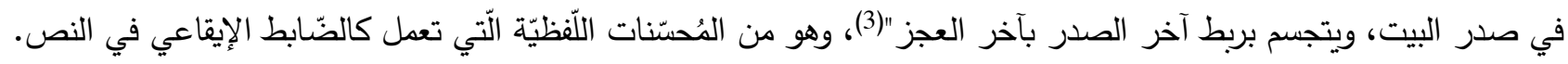
اهتمّ شعراء ديوان العودة بمطالع القصائد اهتمامًا كبيرًا، ويزخر الديوان بالقصائد التي اعتمدت علئ بليه. من أمثلة التصريع في المطالع قول حسام شبلاق(4) : وكـــم فــي الكــونِ مسـن بــالكٍ بـــلا مُقــلِ

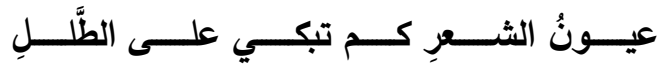

فالتصريع في قوله في آخر الثطر الأول (الطللِ)، وفي آخر الثطر الثاني قوله (مقلِ) والثاعر بهذا التصريع الذي يبدأ

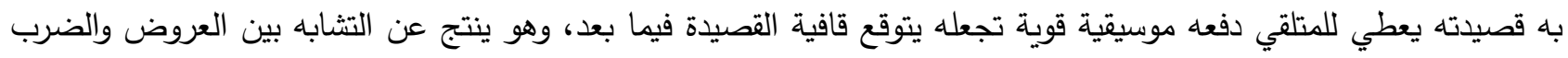

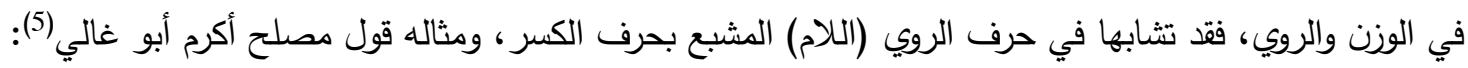
وعواطِفا

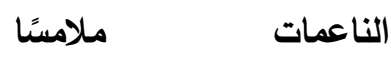
ولطائفِا
محاسنًا
الطيبات

يتعدد الثاعر الإتيان بالتصريع في البيت الأول(ولطائفا) و(وعواطفا)، فالكلمتان متساويتان في الحركات والسكنات (الوزن)، وفي حرف الروي، وبذلك يتعدد إظهار الموسيقى من البيت الأول في النص، ومنه قول خالد صبحي الثرباصي(6): (173/1) القيرواني، العمدة(1) (527).

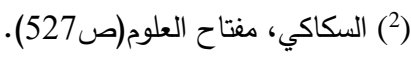
(3) الطرابلسي، خصائص الأسلوب في الثوقيات(صاتصان(83).

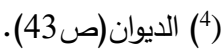

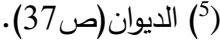

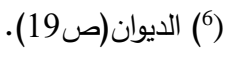




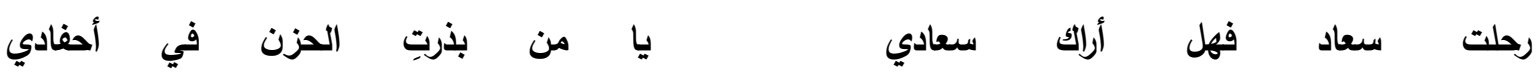
وقد يبدأ الثاعر بالبيت الأول والثاني مستعينا بموسيقى التصريع كما في قول منى أحمد حمادة(1):

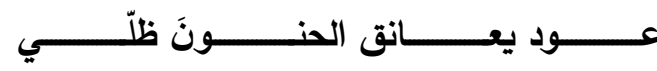

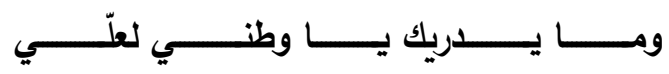

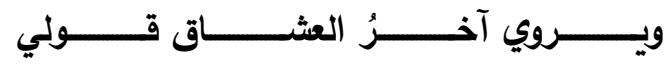

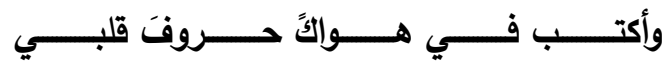

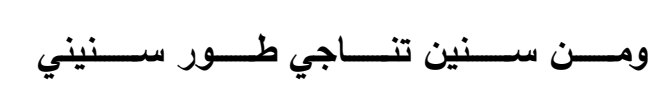
ومنه قول مصطفى منصور (2):

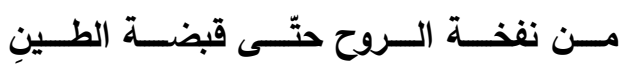
مــن نخـــل بيســـانَ والزيتـــونِ والتـــينِ مــــن زعتـــــر الأرض مشـــــتاقًا لحنـــــونِ

وقد يكون التصريع في البيت الأول والثالث ، ومنه قول شحدة العالول(3): بالصور عبق يتدفق بالصورِ

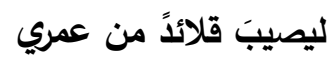

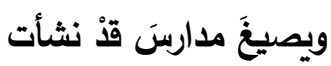
ضربت كملامح للظفرِ فحديثك جدّي كالنظرِ كضياء الفجر وكالمطرِ

ويلاحظ أن الثعراء شديدو الحرص على التصريع، لذا قد نجده وسط القصيدة ومثاله في قول محمد نضال الزعنون في مطلع قصيدته يقول(4):

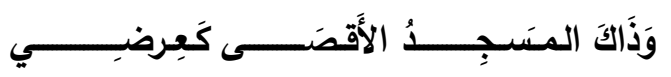

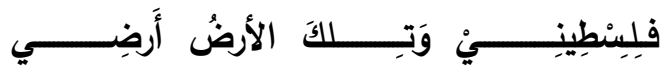

\section{وفيها يقول):}

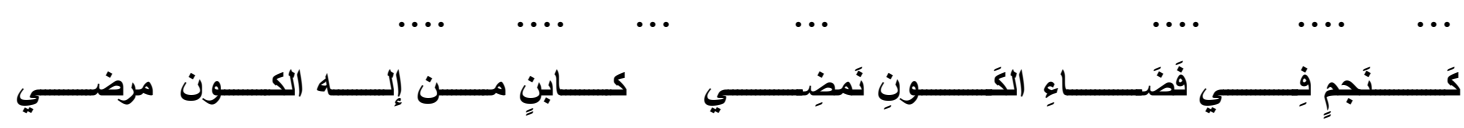

وبذلك يكون الثاعر قد استخدم التصريع في بداية قصيدته حرصًا منه على جذب انتباه المتلقي من بداية القصيدة وفي وسطها بحيث يبقى مشدودًا من خلال الموسيقى الداخلية التي يسببها التصريع •

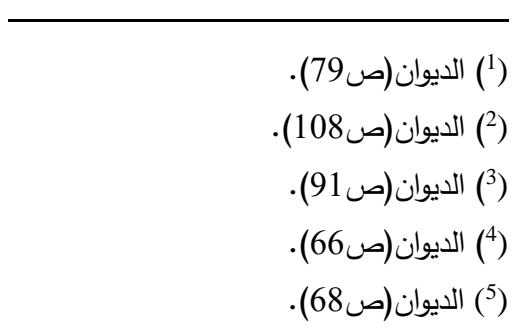


لمّـــــــــا تصــــــــت للعــــــــو صــــــــورنا

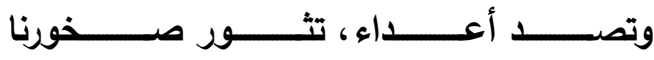

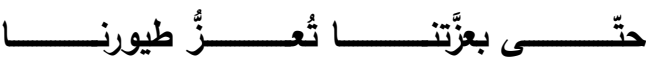

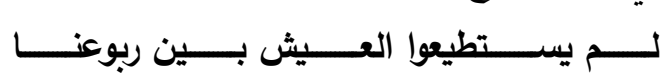

وفيها يقول(2):

ويأتي التصريع في آخر القصيدة ومثاله قول كوثر إبراهيم العصار (3):

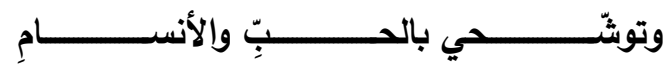

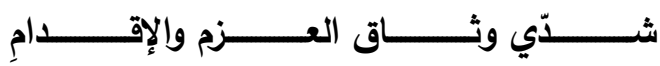

فإذا كان المتلقي قد لفت انتباهه التصريع في مطلع القصيدة، فإنّ الثاعر يريد منه أن يبقى هذا الاهتمام والانتباه إلى

آخر القصيدة، فيأتي له بالتصريع وسطها وآخرها، ليضمن بذلك بقاء المتلقي معه فيشد انتباهه ولا يغادر القصيدة أبداً .

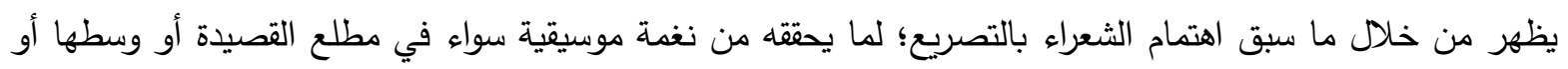

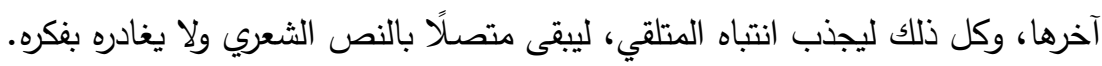

2.

الترصيع من المظاهر الموسيقية في ديوان العودة، وهو "أن يتوخى فيه تصيير مقاطع الأجزاء في البيت على سجع أو شبيه

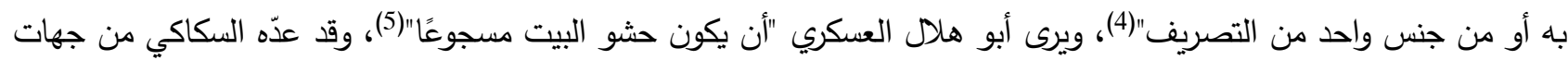

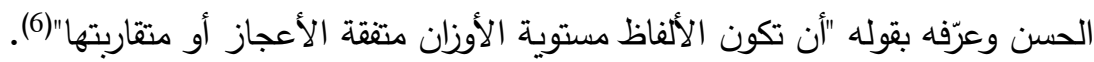

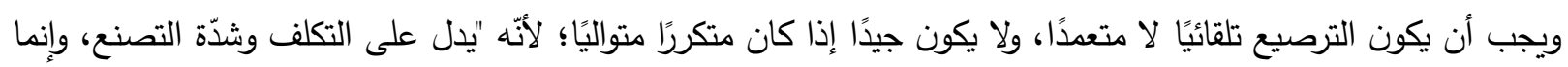
يحسن إذا وقع قليلًا..." (7).

يبدو من خلال التعريفات السابقة أنّ للترصيع أهمية موسيقية في الثعر بحيث تتساوى بعض المفردات مع بعضها

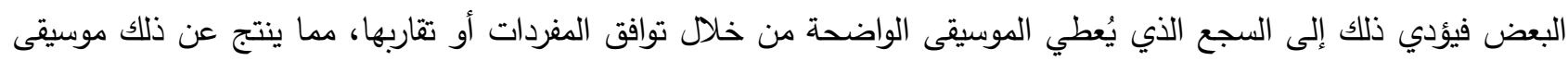
داخلية في النص الثعري، ومثاله قول مصطفى منصور (8):

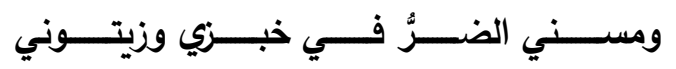

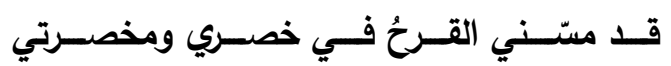

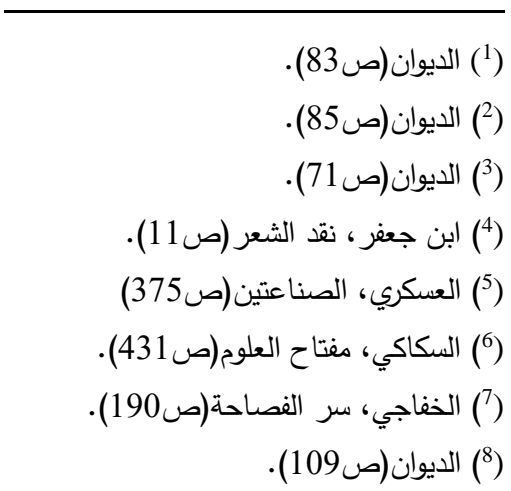


يتعدد الثاعر أن يساوي بين الألفاظ على سجع في حثو البيت كما هو ملاحظ في المفردات (قد مسني القرح) و (ومسني الضرٌ)، و (في خصري) و (في خبزي)، و(ومخصرتي) و (زيتوني)، وهذا التوافق بين المفردات أو شبه التوافق يؤدي إلى إظهار موسيقى الحشو في البيت ليكتمل مع موسيقى الوزن والقافية في القصيدة . ومنه قول سمية وادي(1):

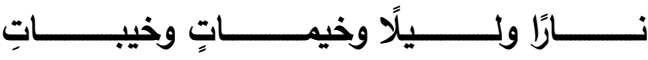

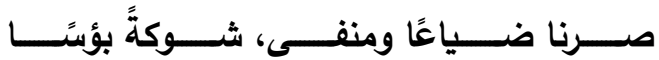

يتضح الترصيع في البيت السابق؛ لأنّ الفقرات متفقة في الوزن والقافية وهي (ضياعًا ومنفى) (شوكة وبؤسًا)، و(نارًا) و (ليلًا)، و(خيماتٍ) و (خيباتِ) مما يعطي البيت موسيقى ظاهرة في حشوه ، فيؤثر في المتلقي ويشدُّ.

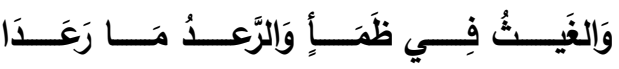

$$
\text { ومنه قول حسن أبو قادوس (2): }
$$

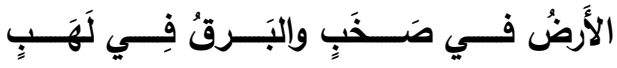

ومن الملاحظ أنّ الثاعر قسَّم الثطر الأول والثاني إلى جمل شبه متساوية(الأرض في صخب) و(البرق في لهب)، و(الغيث

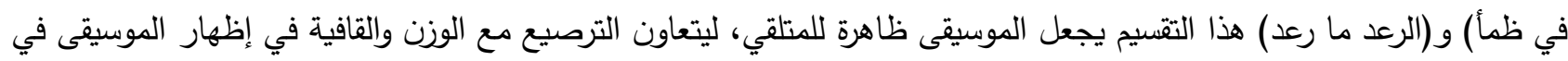
القصيدة.

وقد يأتي الترصيع بين الثطر الأول والثطر الثاني ، ومنه قول سمية وادي(3):

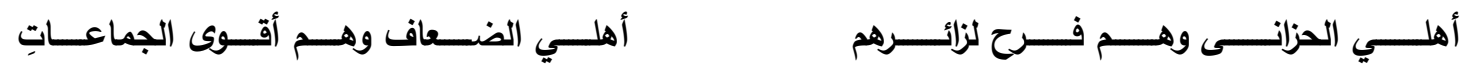

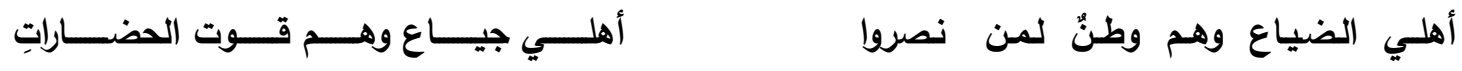
ومنه قول مصلح أبو غالي (4):

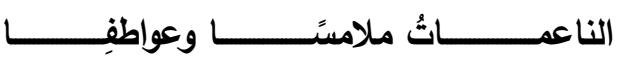

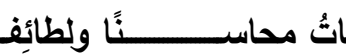
الطيب

تبدو الموسيقى في الأبيات السابقة واضحة للمتلقي وخاصة في التصريع والترصيع ومن الوزن والقافية ومن تكرار حرف الألف وهو حرف مد في الثطرين، هذه الظواهر الموسيقية تتعاون فيما بينها لإظهار موسيقى القصيدة من أولها إلى آخرها، مما يؤثر في المتلقي وشعوره، فالموسيقى يعيش من خلالها المتلقي في عالم الإحساس والخيال.

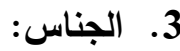

اهتم علماء البلاغة بالجناس اهتماءًا كبيرًا؛ فقد عرّفه معظم البلاغيين والنقاد منذ وَضْع الأسس البلاغية والنقدية، وقد

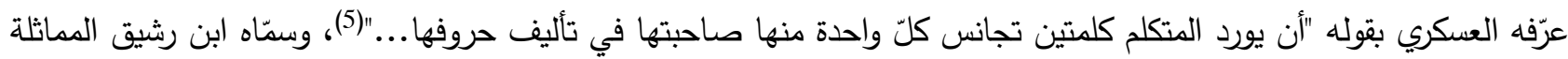

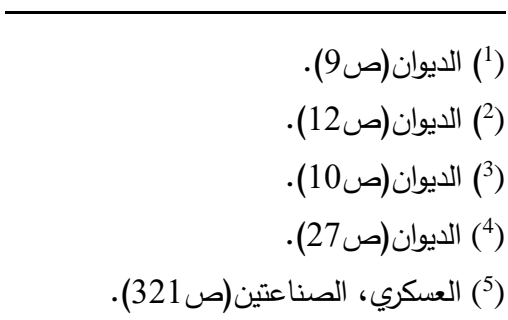


وعرّفه بقوله "أن تكون اللفظة واحدة باختلاف المعنى"(1)، وعرّفه المحدثون بقولهم: "تثابه الكلمتين في اللفظ، واختلافهما في المعنى"(2)، ويقسمونه إلى أقسام كثيرة، لكنّه في الوقت نفسه "يتطلب المهارة والبراعة، وقد لا يقدر عليه إلا الأديب الذي وهب حاسة مرهفة في تذوق الموسيقى اللفظية..."(3). لا شك أن الجناس من المحسنات التي اهتم به النقاد والبلاغيون، وأولوه اهتمامًا واضحًا في كتب النقد والبلاغة؛ لأنّه "يعتمد

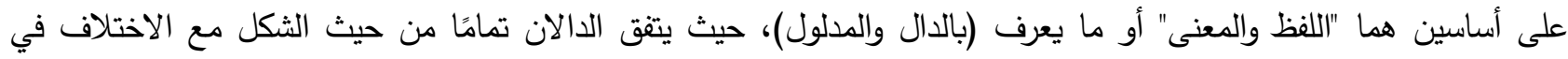
المضمون"(4)، ويعذّ ميزة من مميزات الثعر خاصة في موسيقى الحشو، إذ لا يمكن التقليل من شأنه؛ لأنّه يكمل موسيقى الثعر مع الوزن والقافية والتصريع...، وبذلك تكتمل موسيقى القصيدة، فهما "مقطعان متفقان في الإيقاع مختلفات في المدلول"(5). إنّ القارئ لديوان العودة يتضح له هذا النوع من الموسيقى وبشكل واضح لا غموض فيه، فالثعراء يميلون إلى استخدامه بكثرة، حتى استخدموه بجميع صوره التامة والناقصة...، ويزخر الديوان بمختلف الأشكال، فالثعراء يدقون على أوتاره، ويعزفون عليها عزفًا ماهرًا بإيقاعاتها، خبيرًا بأصواتها، ولذلك فإنَّ النظر إلى الجناس بأنواعه المختلفة، يرد في شعرهم لتكتمل الصورة

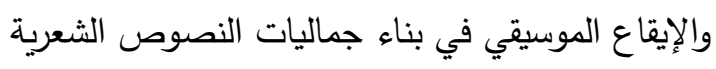
ومن الملاحظ أن الجناس في الديوان يأتي في صور عدّة منها : الجناس بمراعاة التصدير ، ويكون "في إيراد اللفظ

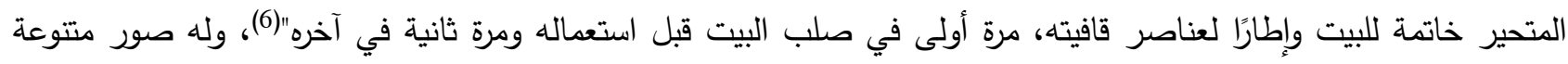
منها قول محمد الزعنون(7):
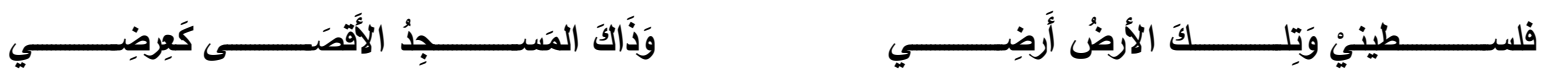

وهذا النوع كثيرًا ما يكون في مطلع القصائد؛ لأنّ الثاعر ملتزم بالتصريع والجناس واضح في البيت السابق في قوله "أرضي" و "عرضي" وهذا يولد شكلًا من أشكال الموسيقى الداخلية مع التصريع في مطلع القصيدة. ومنه قول أماني محمد عمارة(8) : رهن

والثــــمس مـــن حــــزّ النــــوى تتلحَّــــنُ

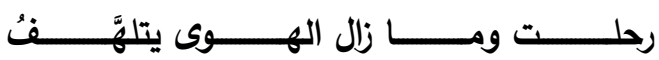
ومن صور الجناس المتعددة في الحشو عدا التصريع قول أنس الحاج محمد أحمد(9):

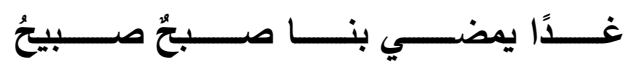

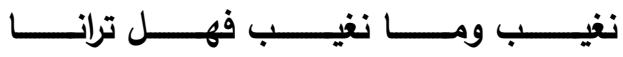

(1) القيرواني، العدة في محاسن الثعر وآدابه(ج1/121/).

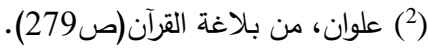

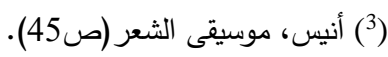

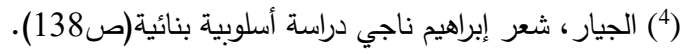

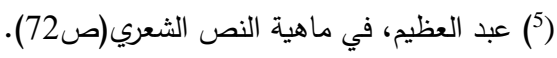
(6) الطرابلسي، خصائص الأسلوب في الثوقيات(صالصة65).

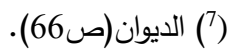

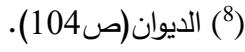

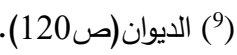


يبدو الجناس في قول الثاعر(صبح) وهي بمعنى فجر ليوم جديد، أي ميلاد لعهز جديد، و(صبيح)بمعنى جميل، والجناس واضح بين الكلمتين في تثابهما في معظم الحروف، مع اختلاف المعنى، وهذا التثابه يُعطي انطباعًا موسيقًا في المتلقي، ومن الجناس قول خليل نصار (1):

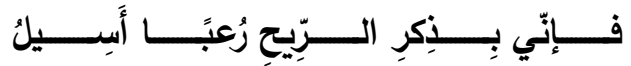

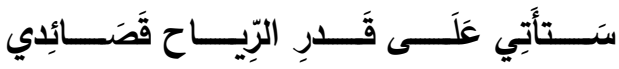

فالجناس الناقص واقع بين(الرياح) التي هي للخير والبركة، وبين(الرّيح) التي هي للدمار والعذاب (رعبًا). ومن أمثلة الجناس بين الاسم والفعل قول علا زياد أبو سبلة(2):

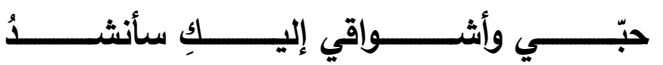

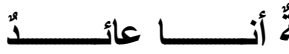

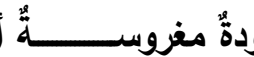
أنثـ

فالجناس واقع بين الاسم (أنشودة) و(سأنثد) مما يثير انتباه المتلقي لما به من موسيقى ظاهره.

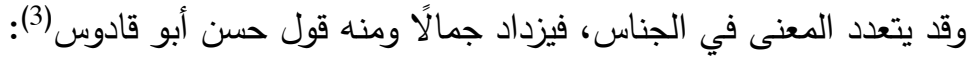

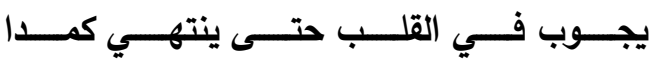

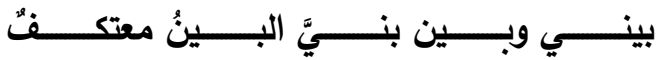

إنّ الكلمات (بيني، بنيّ، البين) بينها جناس، لكنّها لا تلتقي فقط في حروفها، وإنّما في إيقاعها، أما ما تعبر عنه وتوضحه من معنى فذلك ما يهدف إليه الثاعر، البعد الذي أصاب الفلسطينيين بعد تهجيرهم عن أرضهم صار ملازمًا لهم في

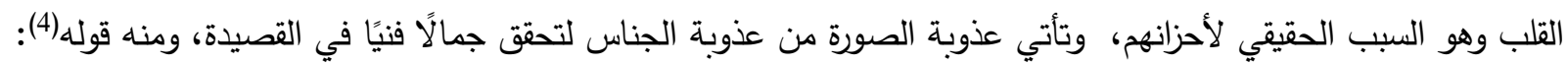

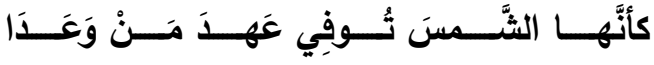

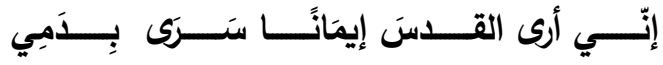
ومنه قول حامد القريناوي(5):

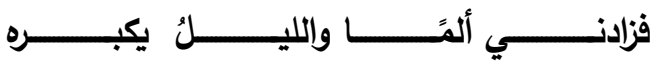

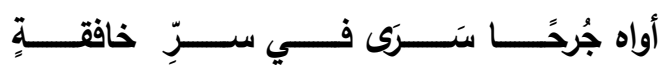

$$
\begin{aligned}
& \text { ومنه قول مجدي معين قنن (6): } \\
& \text { يـا بـلادًا هـي من عُهدة جدِّي... } \\
& \text { سوف يبقى عهُ جدّ الطين فينا }
\end{aligned}
$$

وهكذا نجد أن الشعراء في ديوان العودة يستخدمون الجناس بصورة يمكن ملاحظتها، وبأشكاله المتعددة، ويأتي هذا الجناس في شعرهم طائعًا ولينًا جميلًا، ولن يقف دور الجناس على ما يحققه في النص من جرس موسيقى، بل قد يتعداه إلى أغراض أخرى،

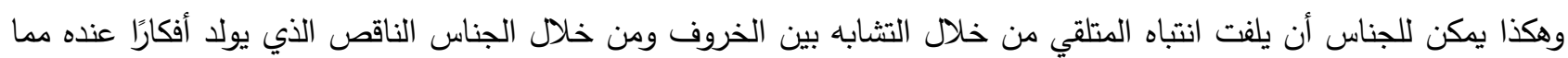
يترك عنده انطباعًا إيجابيًا وشعوريًا.

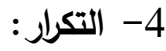

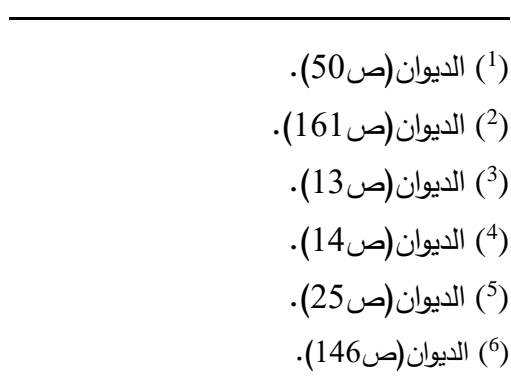


عرف النقد العربي التكرار بالترديد، ويراه ابن رشيق عندما "يأتي الثاعر بلفظه متعلقة بمعنى، ثم يردها بعينها متعلقة بمعنى

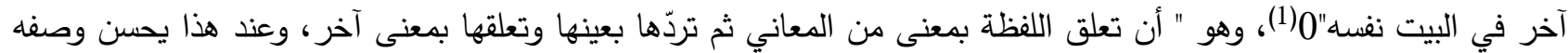
ويعجب تأليفه" (2).

إنّ ظاهرة التكرار في الثعر العربي قديمه وحديثه تثكل ظاهرة مختلفة ومتتوعة من الحرف، والكلمة، والعبارة، والبيت، وهذه

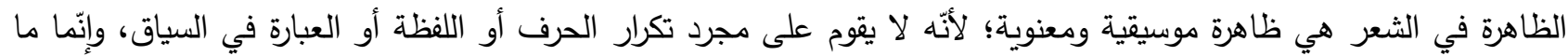

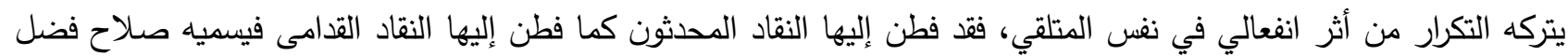
(التدويم)، "... تكرار النماذج الجزئية أو المركبة بشكل متتابع أو متراوح بغية الوصول بالصياغة إلى درجة عالية من الوجد الموسيقي والنشوة اللغوية، عندئذ تتصاعد البنية الموسيقية لتسيطر على المستوى التصويري...."(3). كما أنّ للتكرار دورًا في " لفت النظر إلى المدلول عن طريق الإيقاع الصوتي نفسه أو تخليصه مما يلبس معناه، وقد يرد التكرار استجابة لمقتضيات اللغة أو التركيب أو الإيقاع..."(4)، كما قد يرد استجابة للقافية التي هي عنصر الإعاعر من عناصر الإيقاع الموسيقي. عندما يميل الثاعر إلى استخدام التكرار سواء كلمة أو حرف، أو جملة، فإنّه يحقق هدفًا ما، أو التأكيد على أمر آخر ، فهو لا لأل

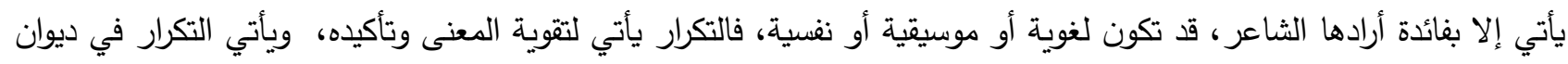

$$
\text { أعودة بصور متنوعة منها: }
$$

من الظواهر الأسلوبية التي يمكن ملاحظتها في الديوان ظاهرة تكرار أصوات بعينها، ويطلق على الإيقاع الصوتي الإيقاع

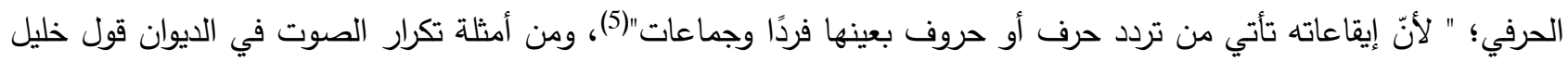
نصار (6):
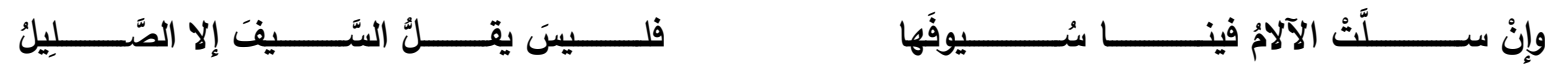

هذا الرنين السيني الزاحف، والهامس على وتر القلب حرك الإيقاع الداخلي والسكونية، ورسم صورة تتجاوز القالب

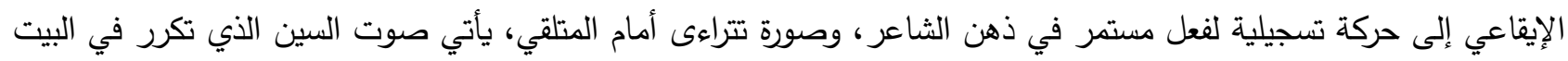

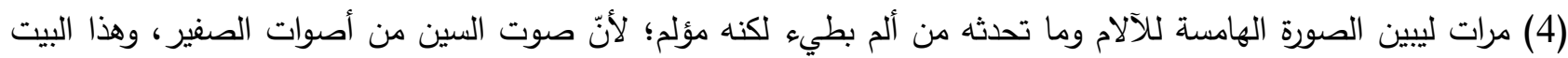

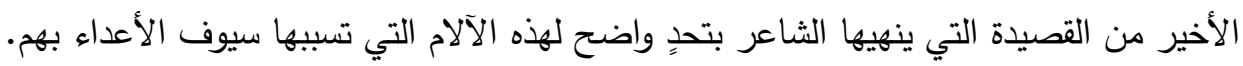
ومنه قول سمية وادي(7): والثـــــــر يُســـــــعُ ســــــاعاتٍ وســــــاعاتِ

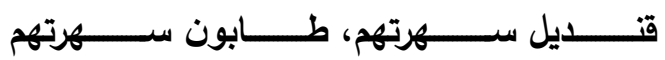


إنّ تكرار صوت السين يأخذ معه في صوت السهرة التي تمتد ساعات وساعات بكل ما في السهرة من سكون وهمس كما في صوت السين، ولو كانت السهرة صاخبة ما تمتّّ هذه المدة، وخاصة إذا كانت السهرة على القناديل والطابون والأشعار. ومن الأمثلة على تكرار الصوت، قول حسن أبو قادوس(1):

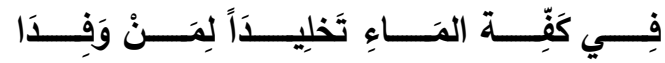

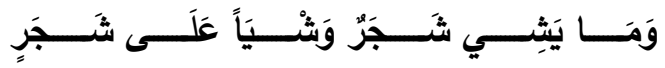

ومن الملاحظ تكرار صوت الثين في الشطر الأول من البيت السابق، وكأنه يوحي على الوشاية بكلِّ هدوء وسكينة، وكأنك تمشي مع صوت الموسيقى الظاهرة من التكرار .

يجــوب فـــي القلـــب حتـــى ينتهـــي كمــــا ومنه قوله (2):

لقد تكرر حرف الباء (6)، وتكرر حرف الياء(8) مرات، وهو حرف مد ولين، وتكرر حرف النون(5) مرات، وهذا التكرار لأصوات بعينها يظهر موسيقى معينة يريدها الثاعر، قد تكون موسيقى فيها حركة وحيوية وقد تكون موسيقى حزينة. ومنه قول علا أبو سبلة(3):

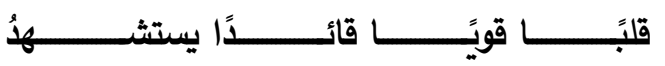

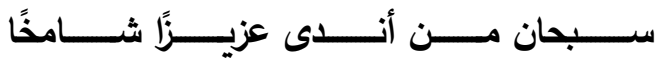

من الملاحظ تكرار صوت القاف في المفردات المتتالية(قلبًا قويًا قائدًا)، وتتميز القاف بصفتين قويتين هما الثدة و الجهر، ولابد أن نحرص على ضبط مخرجها فهو حرف قوي و شديد، وهذه القوة تتاسب المفردات السابقة من حيث قوة القلب

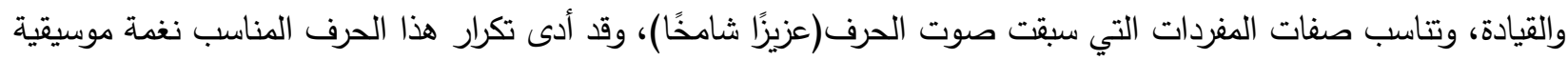
قوية للمعنى المناسب. إنّ شيوع حروف بعينها في الشعر مرتبط بالمعنى الذي يريده الشاعر أولًا، ومرتبط بقدرة الثاعر في توظيف هذا التكرار

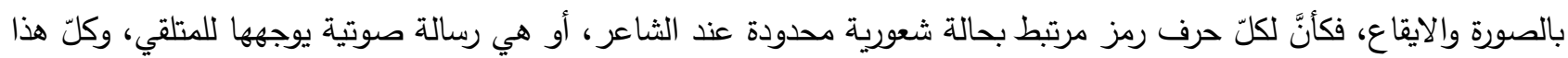
يؤكد أن الشعراء أحسنوا في جعل الحرف جزءاً من الإيقاع. ب- تكرار اللفظ: - ب يلاحظ القارئ لديوان العودة من القراءة الأولى توارد هذه الظاهرة في الديوان، ويتمثل هذا النوع من التكرار في إعادة اللفظة

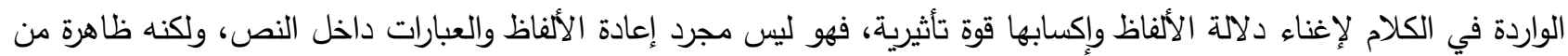
ظواهر التماسك النصي، كما يقوم التكرار على ما تتركه هذه اللفظة من أثر انفعالي في نفس المتلقي، وبذلك يعكس جانبًا من

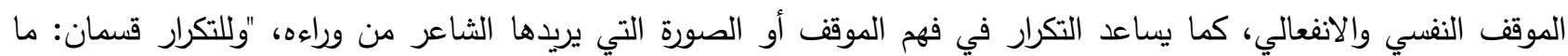
تكررت فيه المادة والصيغة الأولى على حاله، وما تكررت فيه المادة واستخدمت فيه صيغة أخرى دون الصيغة الأولى"(4).

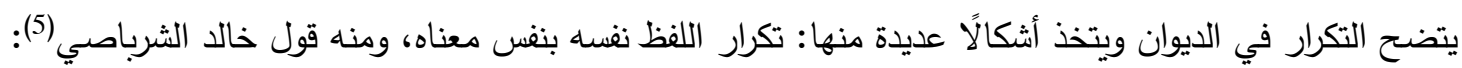

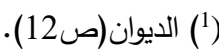

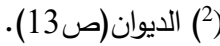

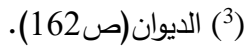

$$
\begin{aligned}
& \text { (4) الطرابلسي، خصائص الأسلوب في الشوقيات (ص262). }
\end{aligned}
$$

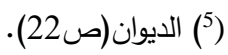




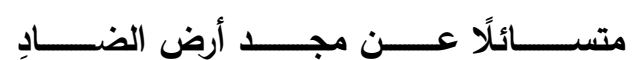

عـــن كــــابر مــــن مطاـــــع الآمـــــادِ

أو لــــــس فنـــــرًا أن تكــــون بــــلادي

وبــــــلاده تســــــقى بمـــــــاء بـــــــلادي

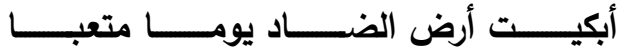

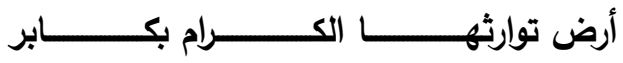

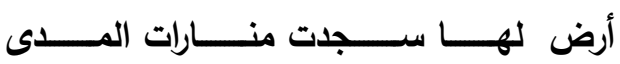

يلاحظ المتلقي التكرار الواضح لكلمة (أرض)التي تكررت(5) مرات في الأبيات السابقة، وهذا التكرار يفيد توكيد ملكية الفلسطينيين للأرض، التي هي بالفعل المؤكد بالتكرار، ومؤكد بالإضافة (أرض الضاد) التي تكررت مرتين في البيت الأول، ودلالة

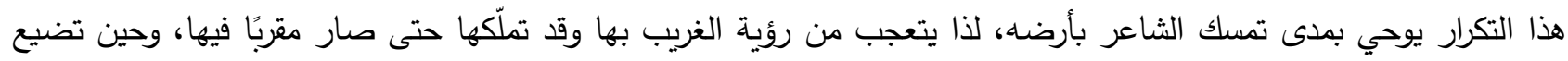

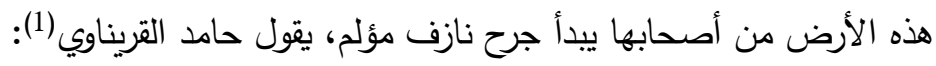

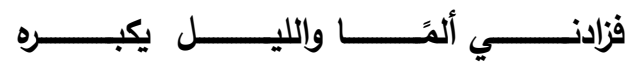

فينبـــري الــــمع مــن عينـــيَّ يثــــهـ

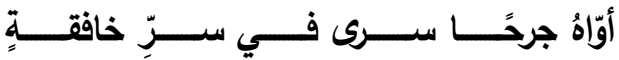

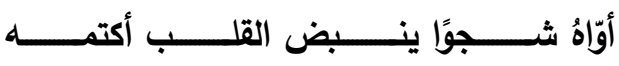

إنّ التكرار في البيتين السابقين لـ (أواه) يوحي بمدى الحسرة الألم من الجرح والحزن الذي أصاب الثاعر لضياع وطنه، وهي بما فيها من تكرار لحرف المد الألف وقبل واو مفتوحة توحي بمدى الألم وشدته، فهو نابع من صميم الثاعر وإحساسه. ومنه قول مصلح أبو غالي (2):

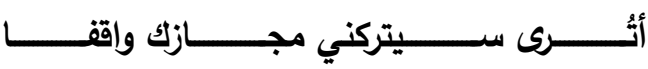

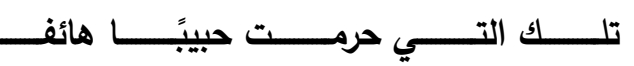

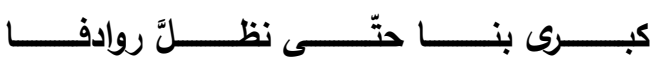

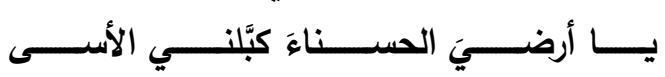
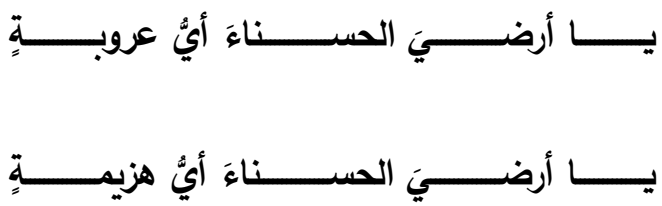

يؤكد الثاعر انتماءه للأرض الحسناء من خلال التكرار(يا أرضيَ الحسناء)، ومن خلال تكرار التقعيلة نفها(3) مرات؛ لتعطي نغمة موسيقية واحدة تتكرر(3) مرات، مع ما فيها من حروف مد تزيد من إيقاع الأبيات، ومن تكرار اللفظ قول محمد الثاعر (3):

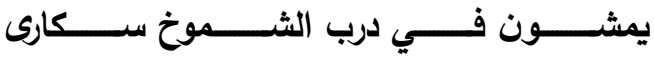

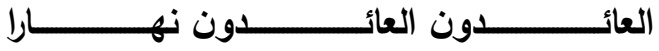


إنّ الإصرار على العودة هو حق طبيعي للثعب الفلسطيني الذي اغتصب الاحتلال أرضه؛ لذا يحلم الثعب الفلسطيني بهذا الحق فيلجأ الثاعر إلى التكرار من خلال تكرار كلمة (العائدون) التي يمشون في دروب الثموخ وهم سكارى من أجلها، كما يلجأ الثاعر إلى التكرار في قوله (1):

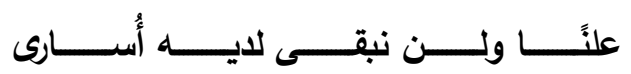

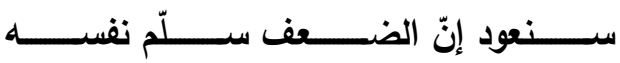<smiles>[As][As]=[As][As]</smiles>

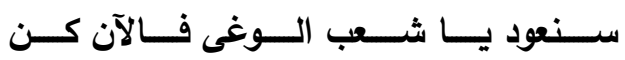

يرى الفلسطينيون العودة حقًا واضحًا لهم، وهي تتكرر في الديوان بكثرة تأكيدًا لهذا الحق الذي لن ينساه صغارهم، وقد

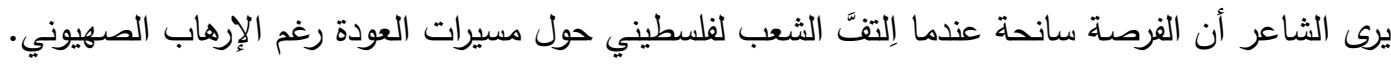
يستبدل مصلح أبو غالي قصيدته (إلى حبييتي الغالية) كلمة (أرضي) بما يدل عليها فهي محبوبته وعشيقته، وهي الإهي

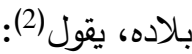

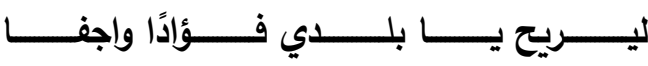

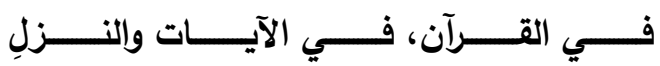

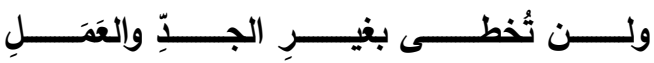

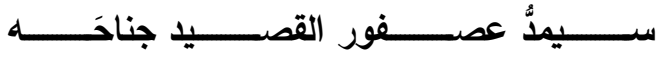

ومنه قول حسام شبلاق(3):
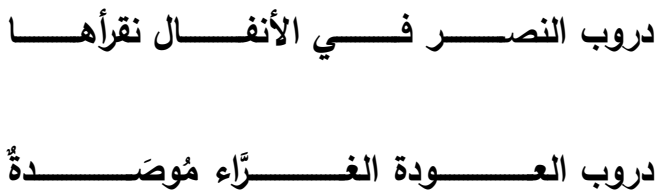

ويبدو التكرار واضحاً في القصيدة، وله رسالة موسيقية تمتزج بالتركيب اللغوي في الجملة الثعرية والنص كلّه، فـ(دروب النصر ) هي(دروب العودة) فلا نصر بلا عودة، ولا عودة بلا نصر ، كما أن القرآن فيه الأنفال والآيات، والجدّ هو العمل. إنَّ المفردات (بلادي، وطني، بيتي، موطني، وطن....) هي الأكثر تكررًا في الديوان.

ومن ذلك قول منتصر أبو عمرة(4): وطني... وينتفض الحنين على شفاهِ من رمادِ

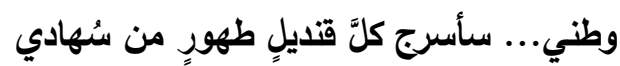

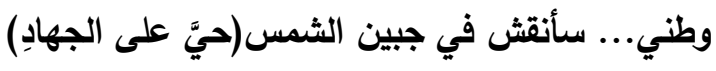
بحقيبتي بيتُّ وسنبلةُّ تحنٌ إلىى الحصَادِ ومآذِنْ ثكلى وزيتونٌ ينادي: يا بلادي وصهيلُ قافية براها الثوق تعزفها جيادي ليدي ليادي 
جاءت المفردات(وطني) التي تكررت ثلاث مرات، و(بيت) و(بلدي) في القطعة السابقة موحية بمدى محبته لها، فهو يحن إليه

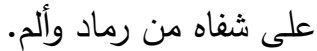

لقد ظهر التكرار في ديوان العودة بثكل واضح، وقد نجد تكرارًا للصوت أو الاسم أو الفعل أو الحرف، وهذا التكرار له غرض في المعنى، وله غرض موسيقي من خلال تكرار الوزن .

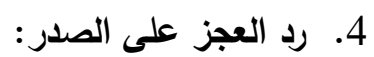

عجزُ البيت هو آخر كلمة في الثّطر الثّاني، وصدر البيت هو آخر كلمة في الثّطر الأوّل، وهو من أحد فنون البديع

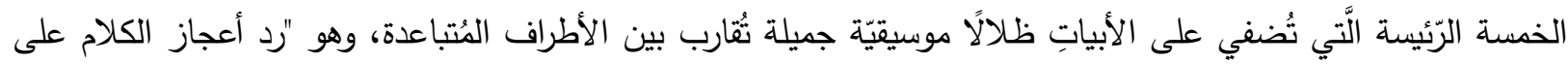
ما تقدمها"(1)، ويعدّها السكاكي من "جهات الحسن... وهو أن يكون إحدى الكلمتين المتكررتين أو المتجانستين أو الملحقتين بالتجانس في آخر البيت والأخرى مثلها..."(2)، وقد يأتي رد العجز على الصدر في النثر كما يأتي في الثعر ، وقد سمّاه بعض البلاغيين بالتصدير، وجعله ابن المعتز من الجناس(3)، ويقوم بعملية تحسين للوزن، ودفع جديد لظاهر التناسب الموسيقي. هذه البنية البديعية في ديوان العودة ظاهرة يلاحظها المتلقي بصورة كبيرة، وعلى أشكال متعددة بحسب موقع الكلمة الموافقة لآخر كلمة في البيت، فقد تكون في الضرب أو يبدأ بها البيت أو تكون أي كلمة من كلمات الحشو.

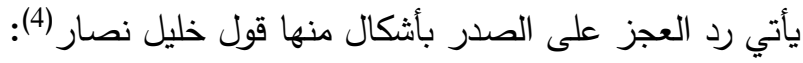
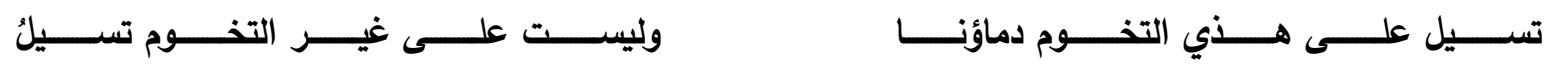

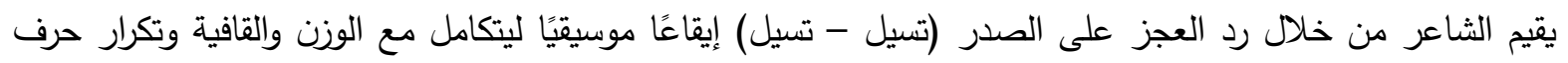
السين(3) مرات، ومن الملاحظ أن رد العزز(تسيل) قد ردها الثاعر على أول كلمة في البيت، فيحقق بذلك إيقاعًا موسيقيًا متكاملًا، فيثد انتباه المتلقي. وقد يقع رد العجز على الصدر في حشو البيت نفسه إما في الثطر الأول، أو في الثطر الثاني، وقد تكرر هذا الثكل

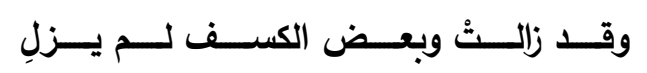

بصورة واضحة في الديوان، ومنه قول حسام شبلاق (5):

والملاحظ في البيت السابق رد العجز على الصدر في قوله : (لم يزل) التي جاءت في آخر البيت وتكررت في حشو الثطر الثاني(زالت)، وقد اعتمد الثاعر عليه وعلى تكرار صوت حروف(الكاف، واللام)، والجناس(نازلة) و (زالت) لإظهار موسيقى البيت. ومنه قول علا أبو سبلة(6):

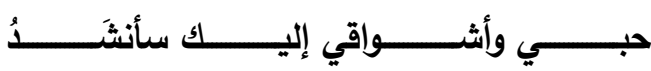

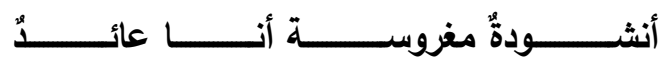

(1) (ابن المعتز ، البديع في البديع(ص140).

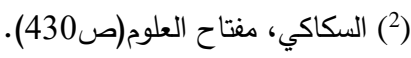
(3) (3) ينظر : عتيق، علم البديع(ص20) (225).

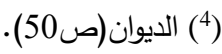

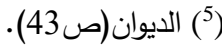

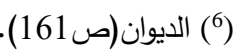


فقد جاء في آخر كلمة من البيت(سأنثد) مع أول كلمة من البيت (أنشودة)،ومنه قول خليل نصار (1):

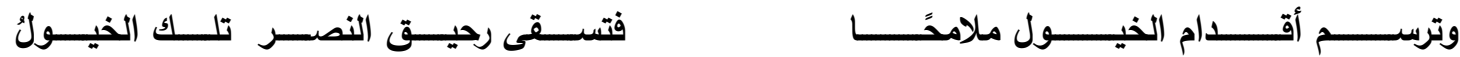
لعل المتلقي يرى كيف استخدم الثاعر رد العزز(الخيول) على حشو في الثطر الأول (الخيول)، ومثاله قول

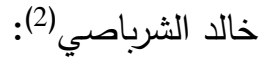

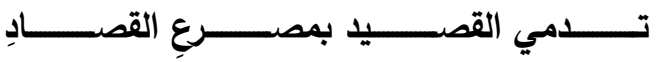

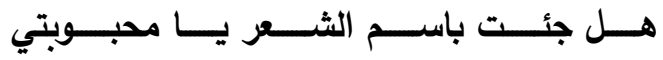

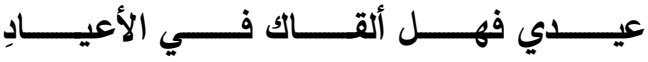

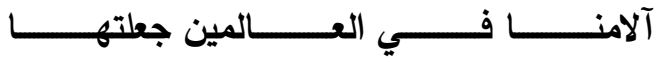

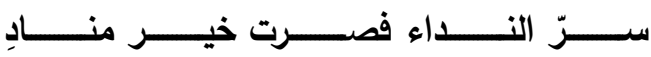

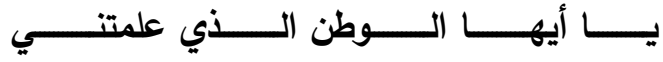

ففي الأبيات جاء رد العجز في قوله(القصاد) و(الأعياد) و(مناد)، على حشو الشطر الثاني (القصيد)، و(الأعياد)، و(عيدي)، على الترتيب، مما كان له الأثر في إظهار موسيقى الابيات. ومنه قول نبراس أبو تيلخ (3):

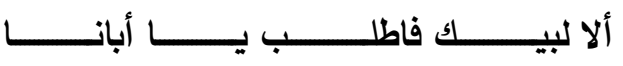

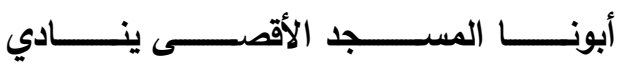

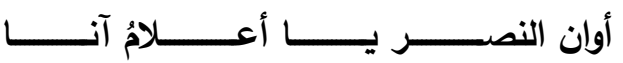

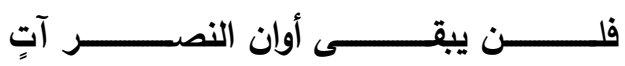

فقد ورد رد العجز على الصدر في البيتين، وبصورتين مختلفتين، ففي البيت الأول في لفظ ورد في عجز البيت(أبانا) وأول كلمة في نفس البيت(أبونا)، وفي البيت الثاني جاء رد العجز (آنا) على حشو الثطر الأول مرة (أوان)، وعلى حشو الثطر الثاني

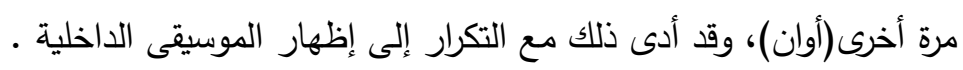
وهكذا يكثر الثعراء من استخدام رد العجز على الصدر وبصوره المختلفة والتي لا يسعنا أن نقف عليها، وإنما المراد إثبات

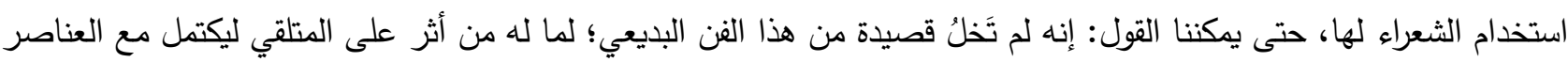
الأخرى جمال موسيقى الثعر في ديوان العودة. الخاتمة

إنّ تجانس الكلمات، وذبذبة التصريع والترصيع، وجمال المطابقات، ورنين الأصوات المقطعيّة، وتكرار الألفاظ والحروف،

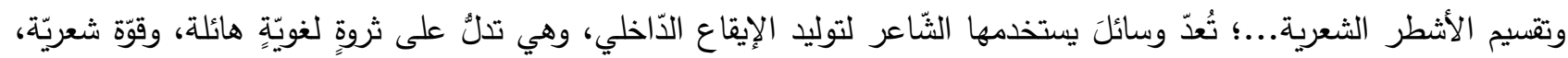
ومهارة بيانيّة، وقدرة على اختيار الموضوعاتِ الحسنة لما يختارهُ من بديع، وقد توصل البحث إلى بعض النتائج منها: - - لم تخلُ قصائد الديوان من التصريع إلا في بعض القصار التصائد، وخاصة في البيت الأول.

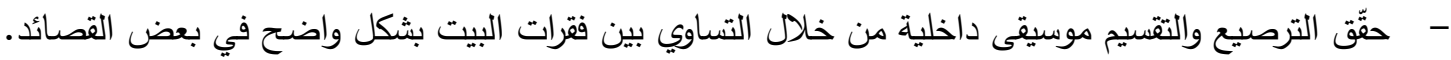
- - - ظهر الجناس بنوعيه التام والناقص في كثير من القصائد وقد حقق موسيقى واضحة. 
- كان للتكرار حضور واضح من خلال تكرار الكلمة أو المقطع أو الحرف وبذلك يحقق تكرار صوتي موسيقي. - - كثيرًا ما يلجأ الثعراء في ديوان العودة إلى رد العجز على الصدر وبأنواعه ؛ لتحقيق موسيقى داخلية. - الإيغال من البديع الذي حقق الثعراء من خلاله موسيقى القافية ليكتمل دورها في موسيقى القصيدة كاملة.

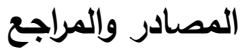

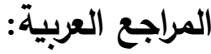

إسماعيل، عزالدين. (1992م). الأسس الجمالية في النقد العربي . القاهرة : دار الفكر العربي.

أنيس، إبراهيم. (د. ت). موسيقى الشعر ـ القاهرة : مطبعة الأنجلو المصرية .

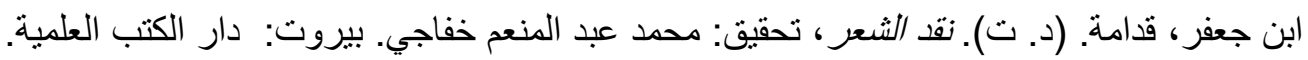

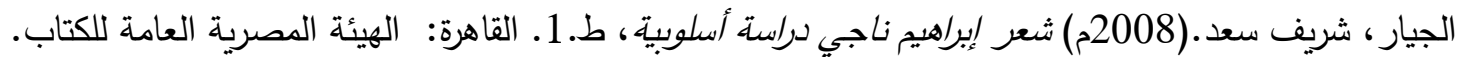
الخفاجي، بن سنان. (1982). سر الفصاحة . ط.1. بيروت : دار الكتب العلمية. السكاكي، يوسف بن أبي بكر (1987م) مفتاح العلوم، ضبطه: نعيم زرزور • بيروت: دار الكتب العلمية، بيروت.

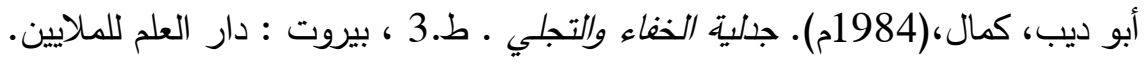

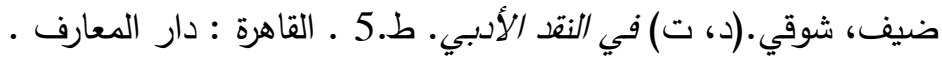
الطرابلسي، محمد الهادي.(1996م). خصائص الأسلوب في الشوقيات ـ ط.1. تونس : المجلس الأعلى للثقافة.

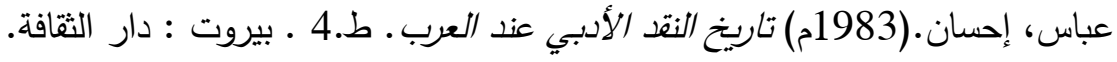

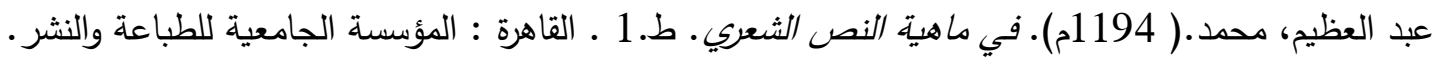
عبد المطلب، محمد.(1997م). هكذا تكلم النص. القاهرة: الهيئة الهصرية العامة للكتاب. علوان، محمد شعبان، نعمات شعبان(د. ت) من بلاغة القرآن. ط.6. القاهرة: الدار العربية للتوزيع والنشر .

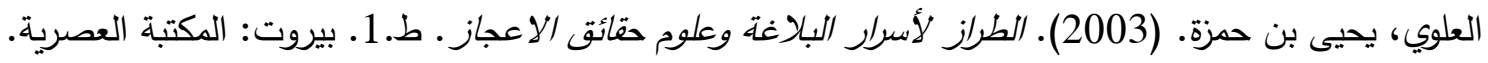

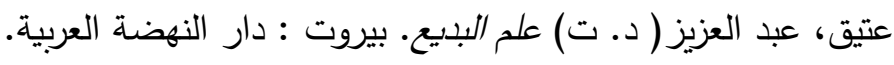

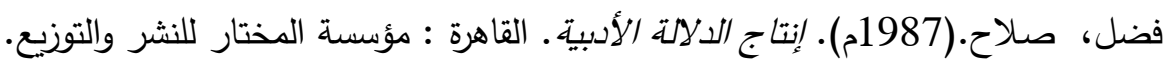
القيرواني ،الحسن بن رشيق. (1981م). العددة في محاسن الثعر وآدابه. تحقيق: محمد محي الدين عبد الحميد. ط.5. بيروت:

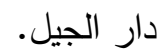

مجموعة من الثعراء الفلسطينيين.(2019م). ديوان العودة. فلسطين. غزة: رابطة والكتاب والأدباء الفلسطينيين.

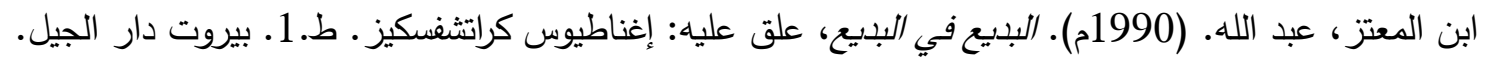

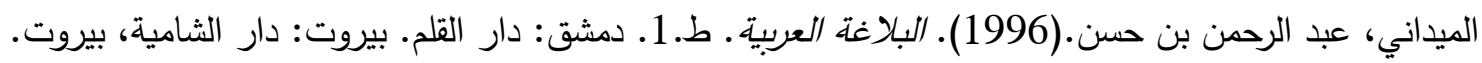

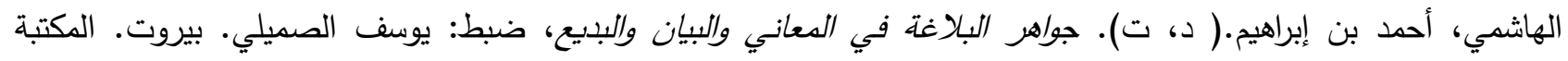
العصرية.

أبو هلال العسكري،(1997م). الصناعتين، تحقيق: محمد البجاوي، محمد أبو الفضل إبراهيم. بيروت: المكتبة العصرية. 


\section{قائمة المراجع المرومنة:}

A group of Palestinian poets,(2019) Diwan al-Awda, (in Arabic).Gaza,Palestine Palestinian Writers and Writers Association.

A; Quyrwany,A(1981), The mayor in the beauties of poetry and its etiquette, (in Arabic). investigation :Muhamed Mohyy El Deen Abed Al hameed, P5 ,Beirut,House of Generation.

Abas,E.(1983). History of literary criticism among the Arabs, (in Arabic) ,P4. Beiurt. House of Culture.

Abd A.(1997). This is how the text speaks, (in Arabic). Cairo. the Egyptian General Book Authority.

Abed A.(1994) In what poetic text is, (in Arabic). P1. University Foundation for Printing and Publishing.

Abo Deeb, K.(1948).The dialectic of invisibility and manifestation,(in Arabic).P3. Beirut. House of science for millions.

Abo Hellal A(1997). The two industries, (in Arabic).investigation, Muhamed El Bejawwy, Muhamed Abo El Faddel Ibraheem , Beirut. Modern Library.

Al ALAAwwi, Y.(2003). Al-Tazj for the Secrets of Rhetoric and the Sciences of the Facts of the Miracles, (in Arabic) ,P1Beirut.Al-Asriyya Library.

Al Asskarry, A.(N.P.).The two industries, (in Arabic). Investigation, Muhamed Albejawwiee,\& Muhamed Abo Al Fadeel Ebraheem . Beirut. Modern Library.

Al Jiar,S. (2008).Naji's poetry is a stylistic study, (in Arabic) .P 1. Cairo. Egyptian General Book Authority.

Al Khafaje, A.(1982). The secret of eloquence, (in Arabic).P1. Beirut. Scientific Books House.

Al Skakeny. Y.(1987).The key to science, (in Arabic). P,1. Settings: Naaen Zarzor, Beirut. Scientific Books House.

Al Trablsii,M.(1996). Characteristics of method in euphemisms, (in Arabic). P1. Tunisia. Supreme Council of Culture.

Anees,E,(N.P.) .Poetry Music, Anglo-Egyptian Press, (in Arabic). Cairo

Ateeq, A.(N.P). Arab Renaissance House, (in Arabic). Beirut, Lebanon.

Deff,S,(N.P.). In literary criticism, Knowledge House, (in Arabic) .P5. Cairo.

Ebn Al Moutazz. A.(1990). Budaiya in Budaiya, (in Arabic) P1..comment by:Egantyooss Kartchfsky, Beirut. House of Generation.

El Hashmie,A.(N.P.). The jewels of rhetoric in the meanings, (in Arabic). the statement and the wonderful, setting: Yosoff Elssmylie. Beirut. Modern Library.

El mayydany,A.(1996). Arabic rhetoric, Dar Al-Qalam, Damascus.(in Arabic).P1.Beirut. Dar AlShamiya.

Elwwan, M.(N.P.) .From the rhetoric of the Qur'an, (in Arabic). P6. . Cairo. the Arab House for Distribution and Publishing.

Faddel, S.(1987). Literary Significance Production,(in Arabic).Cairo .Al-Mukhtar Foundation for Publishing and Distribution.

Ismail, E.(1992).Aesthetic foundations in Arab criticism(in Arabic). Cairo. Arab Thought House.

Jaffer.Q.(N.P.). Criticism of poetry, (in Arabic). Beirut. Investigation, Muhamed Abed Al Monaaem Khafagy, Scientific Books House. 